Prepared in cooperation with the lowa Department of Transportation and the lowa Highway Research Board (Project HR-140)

\title{
Floods of June 21-July 1, 2018, in the Floyd River and Little Sioux River Basins, Northwestern lowa
}

Open-File Report 2022-1015 



\section{Floods of June 21-July 1, 2018, in the Floyd River and Little Sioux River Basins, Northwestern lowa}

By Padraic S. O'Shea, Jordan L. Wilson, Jared C. Vegrzyn, and Kimberlee

K. Barnes

Prepared in cooperation with the lowa Department of Transportation and the lowa Highway Research Board (Project HR-140)

Open-File Report 2022-1015 


\section{U.S. Geological Survey, Reston, Virginia: 2022}

For more information on the USGS - the Federal source for science about the Earth, its natural and living resources, natural hazards, and the environment—visit https://www.usgs.gov or call 1-888-ASK-USGS.

For an overview of USGS information products, including maps, imagery, and publications, visit https://store.usgs.gov/.

Any use of trade, firm, or product names is for descriptive purposes only and does not imply endorsement by the U.S. Government.

Although this information product, for the most part, is in the public domain, it also may contain copyrighted materials as noted in the text. Permission to reproduce copyrighted items must be secured from the copyright owner.

Suggested citation:

O'Shea, P.S., Wilson, J.L., Vegrzyn, J.C., and Barnes, K.K., 2022, Floods of June 21-July 1, 2018, in the Floyd River and Little Sioux River Basins, northwestern lowa: U.S. Geological Survey Open-File Report 2022-1015, 35 p., https://doi.org/10.3133/ofr20221015.

Associated data for this publication:

Fiala, S.G., and O'Shea, P.S., 2022, Peak-flow frequency analysis for seven selected U.S. Geological Survey streamgages in the Floyd and Little Sioux River Basins, lowa, based on data through water year 2019: U.S. Geological Survey data release, https://doi.org/10.5066/P9V8NOOH.

0'Shea, P.S., and Fiala, S.G., 2021, Peak-flow frequency analysis for three selected streamgages in the Cedar and Little Sioux River Basins, lowa, based on data through water year 2019: U.S. Geological Survey data release, https:// doi.org/10.5066/P9W7VP64.

U.S. Geological Survey, 2020, USGS water data for the Nation: U.S. Geological Survey National Water Information System database, https://doi.org/10.5066/F7P55KJN.

ISSN 0196-1497 (print)

ISSN 2331-1258 (online) 


\section{Acknowledgments}

The authors want to recognize the lowa Department of Transportation and the lowa Highway Research Board (Project HR-140) for their shared funding of this report.

The authors express their gratitude to Lucinda Parker, public information officer, lowa Homeland Security and Emergency Management, for providing public infrastructure storm damage cost estimates.

The authors also recognize U.S. Geological Survey employees Seth Bishop, Jace Cochran, Dave Conell, Eddie Gorman, Doug Hansman, Roger Haschemeyer, Jon Lageman, Ben Metcalf, Seth Meyers, Geoff Montour, Matt Noon, Tyler Rokes, Chris Temeyer, Scott Thul, Clint Van Schepen, and David Warweg for collecting field data for the determination of water-surface and bench mark elevations listed in this report. 



\section{Contents}

Acknowledgments …...........................................................................................................................

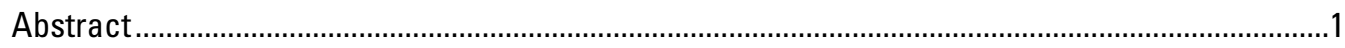

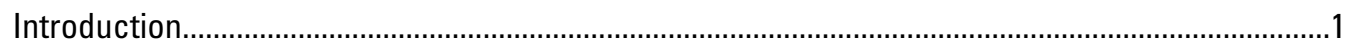

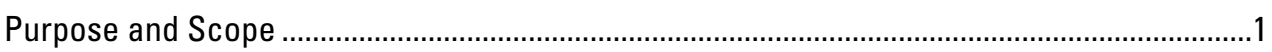

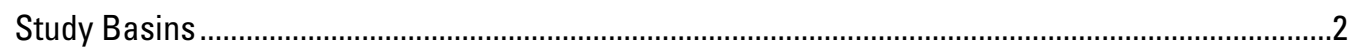

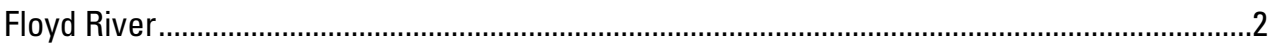

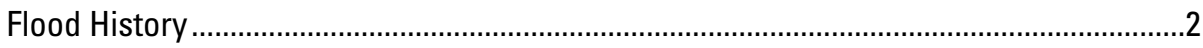

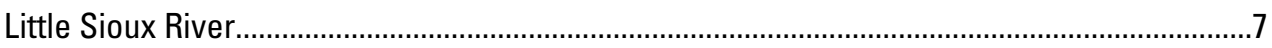

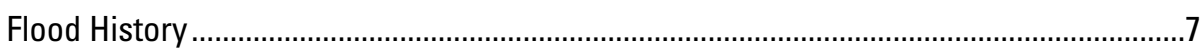

Floods of June-July 2018

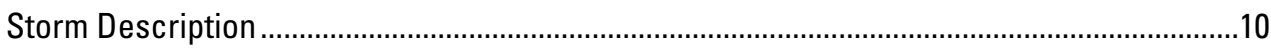

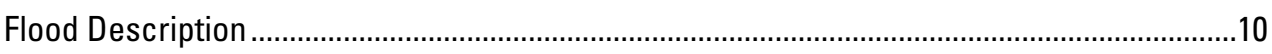

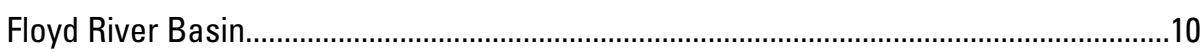

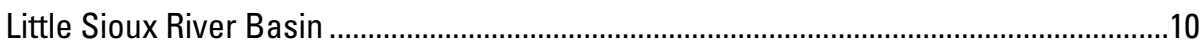

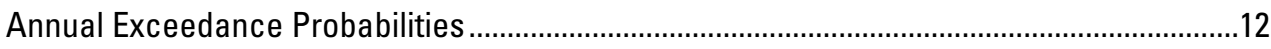

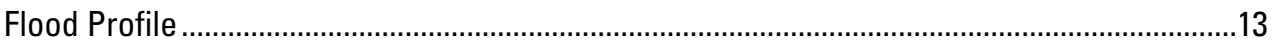

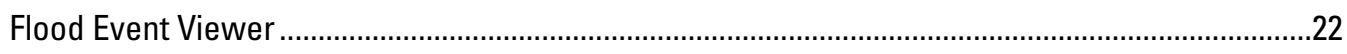

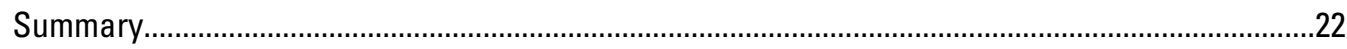

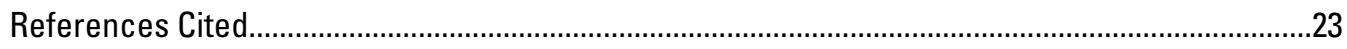

Appendix 1. List of Bench Marks and Reference Points ..........................................................26

\section{Figures}

1. Map showing statewide estimated precipitation for lowa, June 14-21, 2018, and the boundaries for the Floyd River Basin......................................................................

2. Map showing statewide estimated precipitation for lowa, June 14-27, 2018, and the boundaries for the Little Sioux River Basin .................................................................

3. Graph showing discharge for June 21-24, 2018, with annual exceedance probabilities annotated for the U.S. Geological Survey streamgage Floyd River at Alton, lowa

4. Graph showing discharge for June $14-J u l y ~ 24,2018$, with annual exceedance probabilities annotated for the U.S. Geological Survey streamgage Little Sioux River at Linn Grove, lowa

5. Graph showing flood profile of Floyd River, river miles 31.4-84, June 21-24, 2018 ........15

6. Graph showing flood profile of Floyd River, river miles 31.4-45, June 21-24, 2018 .........16

7. Graph showing flood profile of Floyd River, river miles 45-65, June 21-24, 2018 ............17

8. Graph showing flood profile of Floyd River, river miles 65-84, June 21-24, 2018 ............18

9. Graph showing flood profile of Little Sioux River, river miles 95.2-196.2, June 27-July 1, 2018.

10. Graph showing flood profile of Little Sioux River, river miles 95.2-130, June 27July 1,2018 ...

11. Graph showing flood profile of Little Sioux River, river miles 130-170, June 27July 1,2018 ...

12. Graph showing flood profile of Little Sioux River, river miles 170-196.2, June 27July 1, 2018 


\section{Tables}

1. Maximum stage, discharge, and corresponding annual exceedance probability ranges for selected peak flows at streamgages in the Floyd River Basin and Little Sioux River Basin, northwestern lowa.

2. Annual exceedance probability and equivalent flood-recurrence interval for selected probabilities.

3. Locations and elevations of high-water marks used in the Floyd River flood profile, flood of June 21-24, 2018, northwestern lowa.

4. Locations and elevations of high-water marks used in the Little Sioux River flood profile, flood of June 27-July 1, 2018, northwestern lowa

\section{Conversion Factors}

U.S. customary units to International System of Units

\begin{tabular}{lll}
\hline \multicolumn{1}{c}{ Multiply } & \multicolumn{1}{c}{ By } & \multicolumn{1}{c}{ To obtain } \\
\hline inch (in.) & \multicolumn{2}{c}{ Length } \\
foot (ft) & 2.54 & centimeter $(\mathrm{cm})$ \\
mile (mi) & 0.3048 & meter $(\mathrm{m})$ \\
\hline \multicolumn{3}{c}{ Area } \\
\hline square mile $\left(\mathrm{mi}^{2}\right)$ & 1.609 & kilometer $(\mathrm{km})$ \\
\hline \multicolumn{3}{c}{ Flow rate } \\
\hline cubic foot per second $(\mathrm{ft} 3 / \mathrm{s})$ & square kilometer $\left(\mathrm{km}^{2}\right)$ \\
\hline
\end{tabular}

\section{Datum}

Elevation or vertical coordinate information is referenced to the North American Vertical Datum of 1988 (NAVD 88). Elevation refers to distance above or below NAVD 88. The NAVD 88 can be converted to National Geodetic Vertical Datum of 1929 (NGVD 29) by using the National Geodetic Survey Conversion and Transformation Tool available at https://www.ngs.noaa.gov/NCAT/.

Horizontal coordinate information is referenced to the North American Datum of 1983 (NAD 83).

Map projections are Universal Transverse Mercator, Zone 15.

\section{Supplemental Information}

A water year is the 12-month period from 0ctober 1 through September 30. The water year is designated by the calendar year in which the water year ends; thus, the water year ending September 30, 2018, is the "2018 water year." 


\section{Abbreviations}

$\begin{array}{ll}\text { AEP } & \text { annual exceedance probability } \\ \text { FEMA } & \text { Federal Emergency Management Agency } \\ \text { GNSS } & \text { Global Navigation Satellite System } \\ \text { HWM } & \text { high-water mark } \\ \text { MRCC } & \text { Midwestern Regional Climate Center } \\ \text { NOAA } & \text { National Oceanic and Atmospheric Administration } \\ \text { NWS } & \text { National Weather Service } \\ \text { USGS } & \text { U.S. Geological Survey }\end{array}$





\title{
Floods of June 21-July 1, 2018, in the Floyd River and Little Sioux River Basins, Northwestern lowa
}

\author{
By Padraic S. O'Shea, Jordan L. Wilson, Jared C. Vegrzyn, and Kimberlee K. Barnes
}

\section{Abstract}

The Floyd River and Little Sioux River Basins in northwestern Iowa flooded on June 21-July 1, 2018, after sustained rainfall on June 14-27, 2018. Within the Floyd River Basin, rainfall totals from June 14 to 21 preceding flooding were 3.01 inches (in.) at Le Mars, 4.50 in. at Orange City, and 7.44 in. at Sheldon. Within the Little Sioux River Basin, rainfall amounts for the 2-week period from June 14 to 27 preceding flooding were 11.29 in. at Lake Park, 12.95 in. at Milford, 5.56 in. at Spencer, 7.71 in. at Sioux Rapids, and 6.13 in. at Cherokee. Flooding in the Floyd River Basin resulted in a recorded maximum peak discharge of 14,300 cubic feet per second ( $\mathrm{ft}^{3} / \mathrm{s}$; annual exceedance probability [AEP] estimate between 4 and 10 percent) at the U.S. Geological Survey (USGS) streamgage Floyd River at Alton, Iowa (06600100), and a recorded maximum peak discharge of $9,180 \mathrm{ft}^{3} / \mathrm{s}$ (AEP estimate greater than 10 percent) at the USGS streamgage Floyd River at James, Iowa (06600500). Flooding in the Little Sioux River Basin resulted in a recorded maximum peak discharge of $16,300 \mathrm{ft}^{3} / \mathrm{s}$ (AEP estimate between 4 and 10 percent) at the USGS streamgage Little Sioux River at Linn Grove, Iowa (06605850), and maximum peak discharges of $18,700 \mathrm{ft}^{3} / \mathrm{s}$ (AEP estimate greater than 10 percent) and $20,000 \mathrm{ft}^{3} / \mathrm{s}$ (AEP estimate greater than 10 percent) were recorded at the USGS streamgages Little Sioux River at Correctionville, Iowa (06606600), and Little Sioux River near Turin, Iowa (06607500), respectively. Highwater mark elevations were surveyed at 19 locations along the Floyd River and 22 locations along the Little Sioux River to develop 2 flood profiles: a 52.5-mile profile along the Floyd River from State Highway 3 at Le Mars to U.S. Highway 18 at Sheldon that includes the USGS streamgage Floyd River at Alton and a 101-mile profile along the Little Sioux River from U.S. Highway 59 at Cherokee to U.S. Highway 18 north of Spencer that includes the USGS streamgage Little Sioux River at Linn Grove.

\section{Introduction}

Severe thunderstorms during the 10th wettest June on record in northwestern Iowa, including sustained rainfall from June 14 to 27, 2018, resulted in flooding in the Floyd and Little Sioux Rivers on June 21-July 1, 2018 (Iowa Department of Agriculture and Land Stewardship, 2018). As a result, several highways in the upper half of these two basins were closed. The U.S. Geological Survey (USGS) and Iowa Department of Transportation collaborated to document flood profiles by surveying high-water marks (HWMs), calculating annual exceedance probability (AEP) estimates of peak discharges, and summarizing rainfall total amounts from the June 21-27 event along parts of the Floyd and Little Sioux Rivers. In support of the documentation of this flood event, historical flood information for these two river basins also was summarized. Although flooding in September 2018 and March 2019 was greater than flooding in June-July 2018 in the Floyd River and Little Sioux River Basins, flood-profile data were not collected during the September 2018 and March 2019 floods; therefore, flood profiles for the floods of September 2018 and March 2019 are not presented in this report, but brief descriptions of both floods are included for completeness.

\section{Purpose and Scope}

This report is part of an ongoing program of documenting large flood events and the effects of selected highways and bridges on flood levels of rivers and streams in Iowa. The program is funded in cooperation with the Iowa Department of Transportation and the Iowa Highway Research Board (Research Board project HR-140) and is intended to help inform the design of infrastructure within these two basins based on the results of this study and other profiled storm events. A list of other Iowa flood-profile reports is included in Eash (2014) or can be obtained by accessing https://www. usgs.gov/centers/cm-water/science/iowa-flood-information.

This report provides information about the rainstorms and resulting flooding on June 21-July 1, 2018, in the Floyd River Basin and the Iowa part of the Little Sioux River Basin. The estimated AEP ranges of the peak flood discharges at three 
streamgages in the Floyd River Basin and five streamgages in the Iowa part of the Little Sioux River Basin also are described. HWMs at selected sites along the Floyd River are presented in a flood profile from State Highway 3 in Le Mars to U.S. Highway 18 in Sheldon, 52.5 river miles. HWMs at selected sites along the Little Sioux River are presented in a flood profile from U.S. Highway 59 in Cherokee to U.S. Highway 18 north of Spencer, 101 river miles.

\section{Study Basins}

Descriptions of the topography and physiography and the history of flooding for the Floyd River Basin and Little Sioux River Basin are presented in this section. Peak stage and discharge data along with the AEP ranges for the largest known floods, including the June 2018 flood, are listed in table 1 for the streamgages in the Floyd and Little Sioux River Basins.

The data listed in table 1 also are listed in the USGS National Water Information System database (USGS, 2020a), and users may obtain surface-water data for Iowa streamgages, including information on types of data available and years of data collection, at https://waterdata.usgs.gov/ia/nwis/sw.

\section{Floyd River}

The Floyd River is a tributary of the Missouri River in northwestern Iowa, entering the Missouri River at Sioux City (fig. 1). The headwaters are in O'Brien County, near the town of Sanborn. The river flows southwest, primarily through Sioux, Plymouth, and Woodbury Counties. The West Branch Floyd River, the largest tributary to Floyd River with a drainage area of about 282 square miles $\left(\mathrm{mi}^{2}\right)$, enters the Floyd River at Merrill. The drainage area at the mouth of the Floyd River is $921 \mathrm{mi}^{2}$ (Heinitz, 1986).

The Floyd River Basin lies in three of Iowa's landform regions, the Northwest Iowa Plains, the Southern Iowa Drift Plain, and the Loess Hills (Prior, 1991; not shown). The headwaters of the river are on the Northwest Iowa Plains, and the river crosses into the Southern Iowa Drift Plain near Merrill and finally crosses into the Loess Hills about 3 miles (mi) south of Hinton (Prior, 1991). The topography of the Floyd River Basin is highly dissected to gently rolling with major rivers generally flanked by flood plains underlain by uncemented sand-and-gravel deposits (Wahl and others, 1982). More extensive descriptions of the landform regions and physiography of the Floyd River Basin are available from Wahl and others (1982). Land use in the Floyd River Basin is primarily agricultural with some livestock operations (Heinitz, 1986). The Floyd River has been straightened, channelized, lined with riprap, and banked by a high earthen levee through Sioux City (Price, 2010).

\section{Flood History}

Floods on the Floyd River in northwestern Iowa have been well documented after the operation of the USGS streamgage Floyd River at James (06600500; fig. 1), since water year 1935 and at the USGS streamgages Floyd River at Alton (06600100), and West Branch Floyd River near Struble (06600300), since water year 1956; however, before streamgage installation, limited information on historical flooding existed. According to Heinitz (1986, p. 8), the U.S. Army Corps of Engineers reported "three intense storms that caused notable floods in the area," including 13.0 inches (in.) of rainfall on June 23-27, 1891, in Larrabee; 13.6 in. of rainfall on July 14-17, 1900, in Primghar; and 24 in. of rainfall on September 17-19, 1926, in Boyden. According to news reports, the first major flood on the Floyd River occurred on May 18-19, 1892, when 25 people were drowned in Sioux City (Sioux City History, 2021). The 1892 flood was described as the greatest known flood in the Floyd River Basin before 1953 and had a flood elevation of about 1,104 feet (ft) at the 4th Street crossing in Sioux City (Heinitz, 1986). The floods of 1926 and 1934 had flood elevations of just less than 1,102 ft and just less than 1,103 ft, respectively, at the 4th Street crossing in Sioux City (Heinitz, 1986). Descriptions of other floods of note in the Floyd River Basin are described in this section. These floods include the flood events of June 1953, March 1962, June 1983, September 2018, and March 2019.

Flood of 1953.- The flood of June 7-8, 1953, is the largest known flood in the Floyd River Basin. As much as 8.58 in. of rain fell over O'Brien County in about 14 hours with about 7 in. falling over most of the Floyd River Basin (Wells, 1955). A peak discharge of 71,500 cubic feet per second $\left(\mathrm{ft}^{3} / \mathrm{s}\right.$; AEP estimate of less than 0.2 percent) and an estimated peak discharge of $45,500 \mathrm{ft}^{3} / \mathrm{s}$ (AEP estimate of less than 0.2 percent) were recorded at the USGS streamgages Floyd River at James and Floyd River at Alton, respectively (table 1; USGS, 2020a). Flood damages basinwide were extensive to buildings, crops, roads, and bridges, with most of the damage, estimated at about $\$ 23$ million out of a total $\$ 26$ million (1953 dollars), occurring to homes, stores, factories, warehouses, stockyards, and railway equipment within Sioux City (Wells, 1955). These damage estimates are equivalent to about $\$ 216$ million out of a total of $\$ 244$ million in June 2018, dollars according to the U.S. Bureau of Labor Statistics' consumer price index inflation calculator (U.S. Bureau of Labor Statistics, 2022).

Flood of 1962.- The flood of March 28-29, 1962, was the largest known snowmelt-related flood in the Floyd River Basin, before the flood of March 2019. Preceding the flood, the U.S. Army Corps of Engineers estimated between 4 and 5 in. of water-equivalent snow within the Floyd River Basin, and one-quarter to one-half of an inch of rain fell and was absorbed by the heavy snow cover, resulting in no runoff (Rostvedt, 1968). Snow began melting in the days preceding March 27, when accelerated melting occurred and resulted in substantial runoff and flooding (Rostvedt, 1968). A peak discharge of $20,600 \mathrm{ft}^{3} / \mathrm{s}$ (AEP estimate between 4 
Table 1. Maximum stage, discharge, and corresponding annual exceedance probability ranges for selected peak flows at streamgages in the Floyd River Basin and Little Sioux River Basin, northwestern lowa.

[Data are from U.S. Geological Survey, 2020a; dates are listed in month/day/year format; USGS, U.S. Geological Survey; $\mathrm{mi}^{2}$, square mile; ft, foot; ft³/s, cubic foot per second; AEP, annual exceedance probability; IA, Iowa; --, no data; <, less than; >, greater than]

\begin{tabular}{|c|c|c|c|c|c|c|}
\hline USGS streamgage number and name & $\begin{array}{l}\text { Peak-flow record used } \\
\text { (water years) }\end{array}$ & $\begin{array}{c}\text { Drainage area } \\
\qquad\left(\mathrm{mi}^{2}\right)\end{array}$ & $\begin{array}{c}\text { Date } \\
\text { of peak }\end{array}$ & $\begin{array}{c}\text { Peak stage } \\
\text { (ft) }\end{array}$ & $\begin{array}{l}\text { Peak discharge } \\
\left(\mathrm{ft}^{3} / \mathrm{s}\right)\end{array}$ & $\begin{array}{r}\text { AEP range } \\
\text { (percent) }^{1}\end{array}$ \\
\hline \multicolumn{7}{|c|}{ Floyd River Basin } \\
\hline \multirow[t]{7}{*}{ 06600100, Floyd River at Alton, IA } & $1953,1956-2019$ & 268 & 26/--/1953 & -- & 45,500 & $<0.2$ \\
\hline & & & $3 / 28 / 1962$ & 18.35 & 12,200 & $4-10$ \\
\hline & & & $3 / 3 / 1973$ & 15.95 & 2,750 & $>10$ \\
\hline & & & $6 / 20 / 1983$ & 18.54 & 16,300 & $4-10$ \\
\hline & & & $6 / 21 / 2018$ & 20.72 & 14,300 & $4-10$ \\
\hline & & & $9 / 20 / 2018$ & 21.96 & 21,700 & $1-2$ \\
\hline & & & $3 / 14 / 2019$ & 20.87 & 24,900 & $1-2$ \\
\hline \multirow{8}{*}{$\begin{array}{l}\text { 06600300, West Branch Floyd River near Struble, } \\
\text { IA }\end{array}$} & 1956-94, 1996-2019 & 180 & $3 / 28 / 1962$ & 15.63 & 8,060 & $4-10$ \\
\hline & & & $3 / 3 / 1973$ & 14.30 & 3,100 & $>10$ \\
\hline & & & $6 / 20 / 1983$ & 15.86 & 7,590 & $4-10$ \\
\hline & & & $3 / 4 / 1994$ & 15.86 & 8,920 & $4-10$ \\
\hline & & & $7 / 30 / 2010$ & 15.86 & 8,920 & $4-10$ \\
\hline & & & $5 / 27 / 2013$ & 15.77 & 8,280 & $4-10$ \\
\hline & & & $9 / 20 / 2018$ & 15.97 & 5,550 & $>10$ \\
\hline & & & $3 / 13 / 2019$ & 16.00 & 5,630 & $>10$ \\
\hline \multirow[t]{7}{*}{ 06600500, Floyd River at James, IA } & $1935-2019$ & 886 & $6 / 8 / 1953$ & 25.30 & 71,500 & $<0.2$ \\
\hline & & & $3 / 29 / 1962$ & 22.41 & 20,600 & $4-10$ \\
\hline & & & $3 / 4 / 1973$ & 20.46 & 5,660 & $>10$ \\
\hline & & & $6 / 21 / 1983$ & 28.85 & 18,000 & $4-10$ \\
\hline & & & $6 / 23 / 2018$ & 22.09 & 9,180 & $>10$ \\
\hline & & & $9 / 22 / 2018$ & 27.68 & 16,400 & $4-10$ \\
\hline & & & $3 / 15 / 2019$ & 31.48 & 33,500 & $1-2$ \\
\hline
\end{tabular}


Table 1. Maximum stage, discharge, and corresponding annual exceedance probability ranges for selected peak flows at streamgages in the Floyd River Basin and Little Sioux River Basin, northwestern lowa.-Continued

[Data are from U.S. Geological Survey, 2020a; dates are listed in month/day/year format; USGS, U.S. Geological Survey; mi² , square mile; $\mathrm{ft}$, foot; $\mathrm{ft}^{3} / \mathrm{s}$, cubic foot per second; AEP, annual exceedance probability; IA, Iowa; --, no data; <, less than; >, greater than]

\begin{tabular}{|c|c|c|c|c|c|c|}
\hline USGS streamgage number and name & $\begin{array}{l}\text { Peak-flow record used } \\
\text { (water years) }\end{array}$ & $\begin{array}{l}\text { Drainage area } \\
\qquad\left(\mathrm{mi}^{2}\right)\end{array}$ & $\begin{array}{c}\text { Date } \\
\text { of peak }\end{array}$ & $\begin{array}{l}\text { Peak stage } \\
(\text { (ft) }\end{array}$ & $\begin{array}{l}\text { Peak discharge } \\
\left(\mathrm{ft}^{3} / \mathrm{s}\right)\end{array}$ & $\begin{array}{r}\text { AEP range } \\
\text { (percent) }\end{array}$ \\
\hline \multicolumn{7}{|c|}{ Little Sioux River Basin } \\
\hline \multirow[t]{6}{*}{ 06605850, Little Sioux River at Linn Grove, IA } & \multirow{6}{*}{$\begin{array}{l}1953,1961-62,1965 \\
1973-2019\end{array}$} & \multirow[t]{6}{*}{1,548} & $6 / 10 / 1953$ & 20.96 & 22,500 & $2-4$ \\
\hline & & & 23/--/1962 & -- & 10,500 & $>10$ \\
\hline & & & $4 / 7 / 1965$ & 22.25 & 21,000 & $2-4$ \\
\hline & & & $6 / 27 / 2018$ & 23.43 & 16,300 & $4-10$ \\
\hline & & & $9 / 22 / 2018$ & 23.91 & 20,100 & $2-4$ \\
\hline & & & $3 / 16 / 2019$ & 24.01 & 26,400 & $1-2$ \\
\hline \multirow{8}{*}{$\begin{array}{l}\text { 06606600, Little Sioux River at Correctionville, } \\
\text { IA }\end{array}$} & \multirow{8}{*}{$\begin{array}{l}1919-25,1929-32 \\
1937-2019\end{array}$} & \multirow[t]{8}{*}{2,500} & $6 / 12 / 1953$ & 22.09 & 17,500 & $>10$ \\
\hline & & & $6 / 21 / 1954$ & 23.36 & 20,900 & $4-10$ \\
\hline & & & $3 / 30 / 1962$ & 23.14 & 19,800 & $4-10$ \\
\hline & & & 4/7/1965 & 25.86 & 29,800 & $2-4$ \\
\hline & & & $6 / 28 / 2010$ & 23.79 & 27,300 & $4-10$ \\
\hline & & & $6 / 27 / 2018$ & 23.22 & 18,700 & $>10$ \\
\hline & & & $9 / 24 / 2018$ & 24.31 & 23,000 & $4-10$ \\
\hline & & & $3 / 15 / 2019$ & 26.45 & 30,600 & $2-4$ \\
\hline \multirow[t]{9}{*}{ 06607500, Little Sioux River near Turin, IA } & \multirow[t]{9}{*}{$1958-2019$} & \multirow[t]{9}{*}{3,526} & $6 / 14 / 1953$ & 18.35 & 788 & $--^{3}$ \\
\hline & & & $6 / 22 / 1954$ & 24.20 & 7,920 & $--^{3}$ \\
\hline & & & $3 / 29 / 1962$ & 23.97 & 24,400 & $>10$ \\
\hline & & & 4/8/1965 & 26.05 & 27,100 & $>10$ \\
\hline & & & $6 / 22 / 1996$ & 26.99 & 32,000 & $4-10$ \\
\hline & & & $5 / 28 / 2013$ & 25.44 & 31,800 & $4-10$ \\
\hline & & & $7 / 1 / 2018$ & 22.81 & 20,000 & $>10$ \\
\hline & & & $9 / 25 / 2018$ & 23.86 & 22,400 & $>10$ \\
\hline & & & $3 / 15 / 2019$ & 29.57 & 58,400 & $0.2-0.5$ \\
\hline
\end{tabular}


Table 1. Maximum stage, discharge, and corresponding annual exceedance probability ranges for selected peak flows at streamgages in the Floyd River Basin and Little Sioux River Basin, northwestern lowa.-Continued

[Data are from U.S. Geological Survey, 2020a; dates are listed in month/day/year format; USGS, U.S. Geological Survey; mi² , square mile; ft, foot; $\mathrm{ft}^{3} / \mathrm{s}$, cubic foot per second; AEP, annual exceedance probability; IA, Iowa; --, no data; <, less than; >, greater than]

\begin{tabular}{|c|c|c|c|c|c|c|}
\hline USGS streamgage number and name & $\begin{array}{c}\text { Peak-flow record used } \\
\text { (water years) }\end{array}$ & $\begin{array}{c}\text { Drainage area } \\
\left(\mathrm{mi}^{2}\right)\end{array}$ & $\begin{array}{c}\text { Date } \\
\text { of peak }\end{array}$ & $\begin{array}{c}\text { Peak stage } \\
\text { (ft) }\end{array}$ & $\begin{array}{l}\text { Peak discharge } \\
\left(\mathrm{ft}^{3} / \mathrm{s}\right)\end{array}$ & $\begin{array}{r}\text { AEP range } \\
\text { (percent) }^{1}\end{array}$ \\
\hline \multicolumn{7}{|c|}{ Little Sioux River Basin-Continued } \\
\hline \multirow[t]{8}{*}{ 06607200, Maple River at Mapleton, IA } & $1942-2019$ & 669 & $6 / 25 / 1953$ & 17.66 & 11,500 & $>10$ \\
\hline & & & $6 / 20 / 1954$ & 20.40 & 15,600 & $>10$ \\
\hline & & & $3 / 28 / 1962$ & 16.05 & 13,500 & $>10$ \\
\hline & & & $5 / 25 / 1964$ & 15.36 & 11,800 & $>10$ \\
\hline & & & $9 / 12 / 1978$ & 16.74 & 20,800 & $4-10$ \\
\hline & & & $6 / 21 / 1983$ & 16.84 & 17,200 & $4-10$ \\
\hline & & & $6 / 21 / 2018$ & 8.96 & 1,890 & $>10$ \\
\hline & & & $3 / 14 / 2019$ & 23.60 & 26,900 & $1-2$ \\
\hline \multirow[t]{4}{*}{ 06605000, Ocheyedan River near Spencer, IA } & \multirow{4}{*}{$\begin{array}{l}1953,1969 \\
1978-2019\end{array}$} & 426 & $6 / 18 / 1953$ & 12.89 & 26,000 & $<0.2$ \\
\hline & & & $4 / 8 / 1969$ & 11.20 & 12,000 & $2-4$ \\
\hline & & & $9 / 21 / 2018$ & 12.77 & 8,200 & $4-10$ \\
\hline & & & $3 / 15 / 2019$ & 12.71 & 7,130 & $>10$ \\
\hline
\end{tabular}

${ }^{1} \mathrm{AEP}$ ranges reflect the uncertainty of estimating flood-frequency discharges. The exceedance probability is calculated using established techniques but then reported in one of the following ranges: greater than 10 percent, 4-10 percent, 2-4 percent, 1-2 percent, $0.5-1$ percent, $0.2-0.5$ percent, and less than 0.2 percent. The AEP ranges are based on the weighted independent estimates of the at-site flood-frequency quantiles with estimates obtained by regional regression equations following guidelines in appendix 9 of Bulletin 17C (England and others, 2018).

${ }^{2}$ Day of occurrence for this peak is unknown.

${ }^{3}$ Annual peak discharge data from this streamgage before January 9,1958 , are nonequivalent because of diversion. 

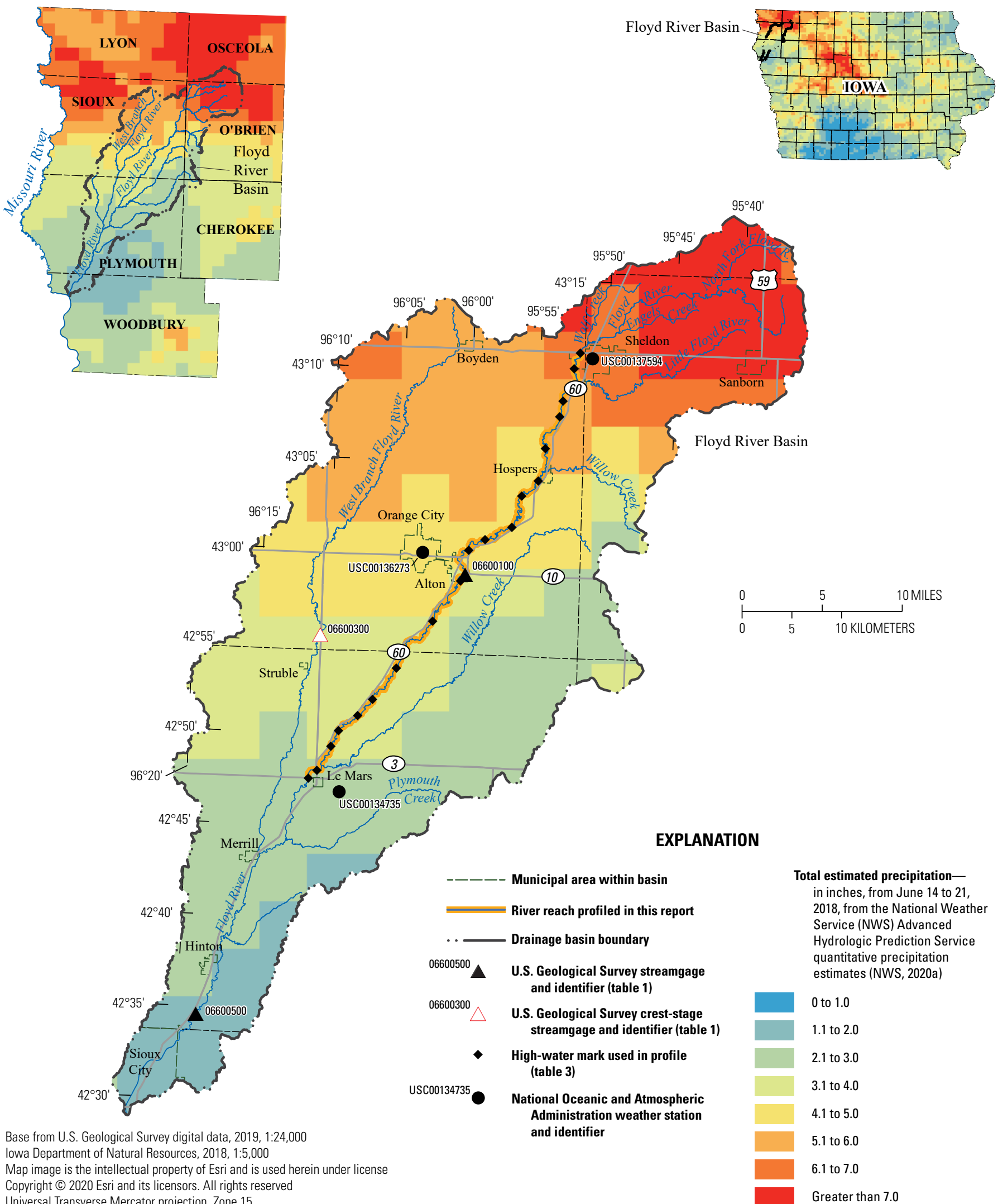

Base from U.S. Geological Survey digital data, 2019, 1:24,000

lowa Department of Natural Resourt

Map image is the intellectual property of Esri and is used herein under license

Copyright (C) 2020 Esri and its licensors. All rights reserved

Universal Transverse Mercator projection, Zone 15

Figure 1. Statewide estimated precipitation for lowa, June 14-21, 2018, and the boundaries for the Floyd River Basin. 
and 10 percent) was recorded at the USGS streamgage Floyd River at James (table 1), and peak discharges of $12,200 \mathrm{ft}^{3} / \mathrm{s}$ (AEP estimate between 4 and 10 percent) and $8,060 \mathrm{ft}^{3} / \mathrm{s}$ (AEP estimate between 4 and 10 percent) were recorded at the USGS streamgages Floyd River at Alton and West Branch Floyd River near Struble, respectively (USGS, 2020a; table 1). The flood of 1962 caused large amounts of damage to roads, bridges, farmland, and farmsteads and forced many families to evacuate from around the levees on the Floyd River; however, it was less damaging than the flood of 1953 (Rostvedt, 1968).

Flood of 1983.- Heavy and persistent thunderstorms brought 2-8 in. of rain on the morning of June 20 over most of the Floyd River Basin, resulting in flash flooding on June 20-21, 1983 (National Weather Service [NWS], 1983). A peak discharge of $18,000 \mathrm{ft}^{3} / \mathrm{s}$ (AEP estimate between 4 and 10 percent) was recorded at the USGS streamgage Floyd River at James (table 1), and peak discharges of $16,300 \mathrm{ft}^{3} / \mathrm{s}$ (AEP estimate between 4 and 10 percent) and 7,590 ft $3 / \mathrm{s}$ (AEP estimate between 4 and 10 percent) were recorded at the USGS streamgages Floyd River at Alton and West Branch Floyd River near Struble, respectively (USGS, 2020a; table 1). Within the Floyd River Basin, at least 3 bridges were knocked out by flooding, damages to crops were extensive, and 1 person was killed (NWS, 1983).

Flood of September 2018. - After substantial flooding in June-July 2018, described in the "Floods of June-July 2018" section, the Floyd River Basin was flooded again between September 18 and 20, 2018, from several rounds of severe thunderstorms. Rainfall totals from 5 to $10 \mathrm{in.} \mathrm{were} \mathrm{recorded}$ across the upper part of the Floyd River Basin, with 2-5 in. across Plymouth County (National Centers for Environmental Information, 2020a). Peak discharges of $16,400 \mathrm{ft}^{3} / \mathrm{s}$ (AEP estimate between 4 and 10 percent), 21,700 ft $3 / \mathrm{s}$ (AEP estimate between 1 and 2 percent), and 5,550 $\mathrm{ft}^{3} / \mathrm{s}$ (AEP estimate greater than 10 percent) were recorded at the USGS streamgages Floyd River at James, Floyd River at Alton, and West Branch Floyd River near Struble, respectively (USGS, 2020a; table 1). Many of the counties in the Floyd River Basin were already covered under disaster declarations from the June-July 2018 flood, and no new counties were declared as a result of the September 2018 flood (Federal Emergency Management Agency [FEMA], 2018).

Flood of March 2019.-The flood of 2019 is the largest snowmelt-related flood on record in the Floyd River Basin (USGS, 2020a). Flooding was the result of rapid snowmelt (1-3 in. of snow water equivalent) and 1-3 in. of rain that fell over much of the basin (1.82 in. at Sheldon and 1.92 in. at Sanborn) on March 13-14 (National Oceanic and Atmospheric Administration [NOAA], 2020a). Peak discharges of $33,500 \mathrm{ft}^{3} / \mathrm{s}$ (AEP estimate between 1 and 2 percent) and $24,900 \mathrm{ft}^{3} / \mathrm{s}$ (AEP estimate between 1 and 2 percent) were recorded at the USGS streamgages Floyd River at James and Floyd River at Alton, respectively (fig. 1), the second greatest flood on record at both streamgages (USGS, 2020a). Flooding was less severe at the USGS streamgage West Branch Floyd River near Struble, where the peak discharge was $5,630 \mathrm{ft}^{3} / \mathrm{s}$
(USGS, 2020a; AEP estimate greater than 10 percent; table 1). Widespread damage across eastern and western Iowa resulted in Presidential or State disaster declarations for all counties in the Floyd River Basin (Iowa Department of Homeland Security and Emergency Management, 2020; FEMA, 2019), and according to news channel KCCI Des Moines, damage across Iowa was to homes (estimated at $\$ 481$ million), businesses (estimated at $\$ 300$ million), agriculture (estimated at \$214 million), roads, and levees (KCCI Des Moines, 2019).

\section{Little Sioux River}

The Little Sioux River is a tributary of the Missouri River in northwestern Iowa, entering the Missouri River at Little Sioux (fig. 2), and has a total drainage area of about 4,500 $\mathrm{mi}^{2}$ (Schwob, 1966). The headwaters are about 11 mi north of the Iowa-Minnesota Border along an east-west line (fig. 2; Schwob, 1966). Three major streams and a combination of lakes and streams drain $308 \mathrm{mi}^{2}$ at the Iowa-Minnesota State line, including the Ocheyedan River $\left(50 \mathrm{mi}^{2}\right)$, the West Fork Little Sioux River $\left(115 \mathrm{mi}^{2}\right)$, the Little Sioux River $\left(101 \mathrm{mi}^{2}\right)$, and a series of small lakes and short intermediate streams (42 $\mathrm{mi}^{2}$; Schwob, 1966). Within Iowa, these streams combine to form the main stem of the Little Sioux River at Spencer, which proceeds to flow southwesterly to the mouth at the Missouri River in Harrison County, intersecting its primary tributary, the Maple River, near Turin (Schwob, 1966).

The Little Sioux River Basin lies in five of Iowa's landform regions, the Des Moines Lobe, the Northwest Iowa Plains, the Southern Iowa Drift Plain, the Loess Hills, and the Missouri Alluvial Plain (Prior, 1991; not shown). The upper part of the Little Sioux River Basin contains lakes of many sizes and is covered by glacial deposits and loess with a flat to undulating topography (Schwob, 1966). The topography then changes in Cherokee County to loess-covered hills and steep slopes predominate along the streams, and the valley floor is narrow until the river reaches Anthon, where the Little Sioux River and Maple River valleys widen and remain wide until the Little Sioux River enters the Missouri River (Schwob, 1966).

Land use in the Little Sioux River Basin is primarily agricultural (Multi-Resolution Land Characteristics Consortium, 2019). The Little Sioux and Maple Rivers have been straightened and leveed south of Smithland and from the mouth to Castana, respectively (Schwob, 1966). An equalizer ditch, which transfers floodwater between the Monona-Harrison ditch and the Little Sioux River, joins the Little Sioux River on the right bank at river mile 21.3 (Schwob, 1966; fig. 2).

\section{Flood History}

Floods on the Little Sioux River in northwestern Iowa have been well documented during the operation of the USGS streamgage Little Sioux River at Correctionville (06606600; fig. 2) since 1918, followed by the USGS streamgages Little 


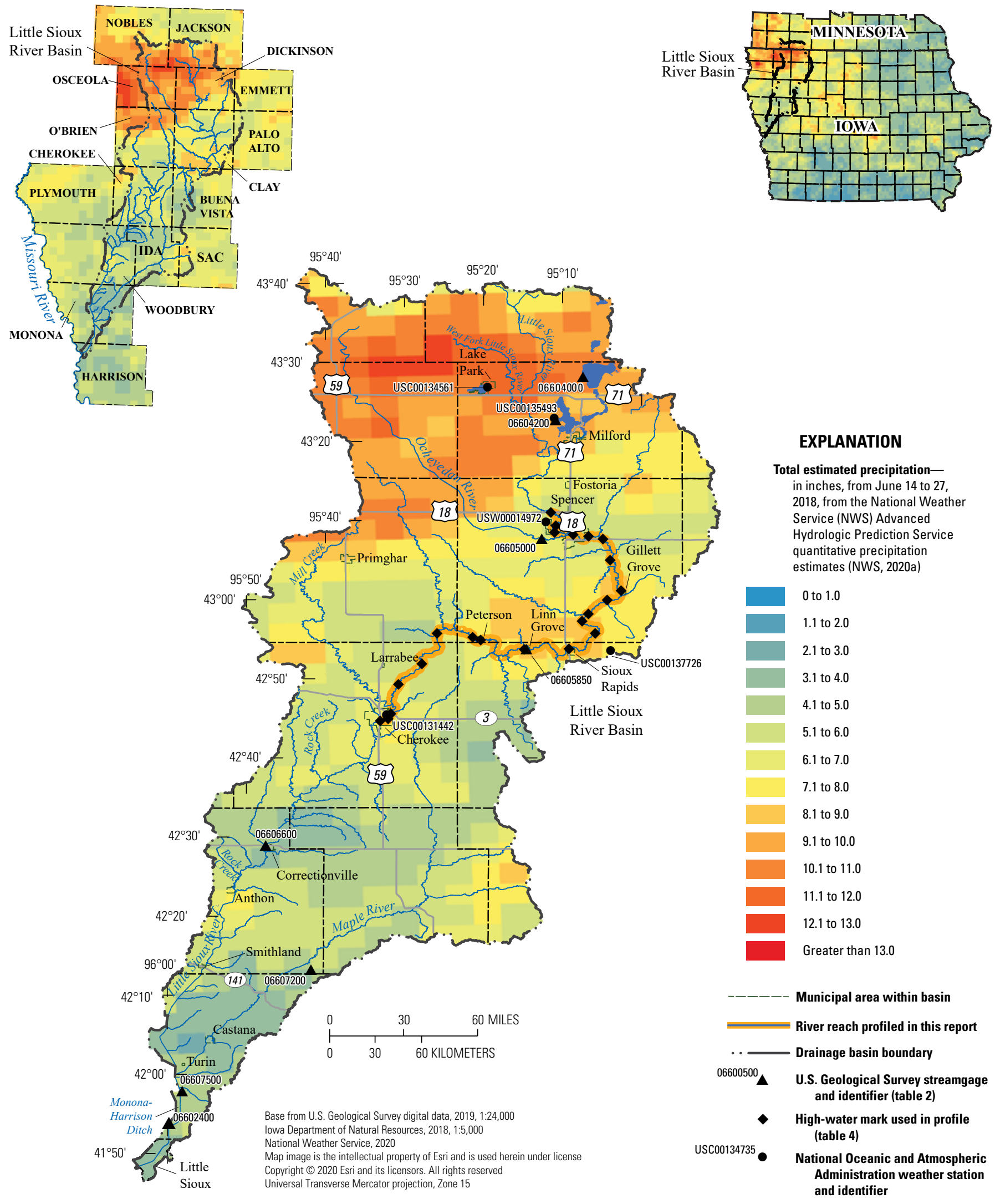

Figure 2. Statewide estimated precipitation for lowa, June 14-27, 2018, and the boundaries for the Little Sioux River Basin. 
Sioux River near Turin (06607500) in 1939, and Little Sioux River at Linn Grove (06605850) in 1972. The Iowa Natural Resources Council reported severe floods in the Little Sioux River Basin in 1851, 1881, 1891, 1902, and 1915. Of these floods, only the flood of 1891 is documented. After $12 \mathrm{in.} \mathrm{of}$ rain fell on and near Cherokee in 12 hours on June 23-24, 1891, widespread destruction and suffering were reported within the Little Sioux River Basin (Schwob, 1966). At Correctionville, an HWM for the flood of 1891 is $3.5 \mathrm{ft}$ higher than the 1965 flood, the maximum for the period of record for the USGS streamgage Little Sioux River at Correctionville; however, a local resident claimed that the mark was high as a result of a nearby mill dam breaking on Bacon Creek (not shown) east of Correctionville (Schwob, 1966). No discharge information was reported for the flood of 1891 (Schwob, 1966). Since the installation of streamgages on the Little Sioux River, numerous floods were identified by Schwob (1966) as outstanding; brief descriptions of each of these floods and more recent noteworthy floods follow.

Flood of June 1953.-On June 7, 1953, as much as 8 in. of rain fell across northwestern Iowa in a 16-hour period (Schwob, 1966), resulting in flooding in the upper part of the Little Sioux River Basin. A historical peak discharge of 22,500 ft $3 / \mathrm{s}$ (USGS, 2020a; AEP estimate between 2 and 4 percent) was measured at the USGS streamgage Little Sioux River at Linn Grove, making the flood of 1953 the second greatest known flooding of the Little Sioux River above Linn Grove (Schwob, 1966). Lower magnitude peak discharges of 17,500 ft $3 / \mathrm{s}$ (AEP estimate greater than 10 percent) and $788 \mathrm{ft}^{3} / \mathrm{s}$ were recorded at the USGS streamgages Little Sioux River at Correctionville and Little Sioux River near Turin, respectively (USGS, 2020a; table 1).

Flood of June 1954. - In June 1954, 5-8 in. of rain fell mostly within a 3-day period (June 17-19), resulting in flooding in the Little Sioux River Basin (Schwob, 1966). The flood of 1954 had lower discharges in the upper part of the basin than the flood of 1953, but discharges were higher in the lower part of the basin. Peak discharges of $20,900 \mathrm{ft}^{3} / \mathrm{s}$ (AEP estimate between 4 and 10 percent) and 7,920 ft3 $3 / \mathrm{s}$ were recorded at the USGS streamgages Little Sioux River at Correctionville and Little Sioux River near Turin, respectively (USGS, 2020a; table 1).

Flood of March 1962.-The flood of 1962 was the result of spring snowmelt in combination with rainfall (Schwob, 1966). Peak discharges of $19,800 \mathrm{ft}^{3} / \mathrm{s}$ (AEP estimate between 4 and 10 percent) and 24,400 ft ${ }^{3} / \mathrm{s}$ (AEP estimate greater than 10 percent) were recorded at the USGS streamgages Little Sioux River at Correctionville and Little Sioux River near Turin, respectively (USGS, 2020a; table 1).

Flood of April 1965.-The flood of 1965 was the third greatest flood on record on the lower part of the Little Sioux River. A snow survey within the Little Sioux River Basin on March 26-29 indicated 6-8 in. of snow water equivalents at Spirit Lake, Iowa (not shown); $2-3$ in. between Spencer and Cherokee; and less than $1 \mathrm{in}$. in the southern part of the basin (Schwob, 1966). Warm temperatures during April 3-6, in addition to about 2 in. of rain, accelerated snowmelt and the frosty ground prevented any infiltration, resulting in record discharges south of Clay County (Schwob, 1966). A peak discharge of $29,800 \mathrm{ft}^{3} / \mathrm{s}$ (AEP estimate between 2 and 4 percent) was recorded at the USGS streamgage Little Sioux River at Correctionville (USGS, 2020a; table 1), and a peak discharge of $27,100 \mathrm{ft}^{3} / \mathrm{s}$ (AEP estimate greater than 10 percent) was recorded at the USGS streamgage Little Sioux River near Turin (USGS, 2020a). A historical discharge of $21,000 \mathrm{ft}^{3} / \mathrm{s}$ (AEP estimate between 2 and 4 percent) was measured at the USGS streamgage Little Sioux River at Linn Grove (USGS, 2020a; table 1). Flood damages in Cherokee were about $\$ 666,000$ in 1965 dollars, which is equivalent to about $\$ 5.4$ million in June 2018 dollars, according to the U.S. Bureau of Labor Statistics' consumer price index inflation calculator (U.S. Bureau of Labor Statistics, 2022), and 360 people were forced from their homes (Schwob, 1966).

Flood of September 2018.- - Several rounds of thunderstorms brought heavy rain to northwestern Iowa on September 18-21, 2018; rainfall totals ranged from 4 to 8 in. (NOAA, 2020b). Peak discharges of 22,400 ft $3 / \mathrm{s}$ (AEP estimate greater than 10 percent), $23,000 \mathrm{ft}^{3} / \mathrm{s}$ (AEP estimate between 4 and 10 percent), and 20,100 ft $3 / \mathrm{s}$ (AEP estimate between 2 and 4 percent) were recorded at the USGS streamgages Little Sioux River near Turin, Little Sioux River at Correctionville, and Little Sioux River at Linn Grove, respectively (USGS, 2020a; table 1). Many of the counties in the Little Sioux River Basin were already covered under disaster declarations from the June-July 2018 flood, and no new counties were declared as a result of the September 2018 flood (FEMA, 2018). Substantial crop and pastureland were flooded, and city and county parks were severely inundated (National Centers for Environmental Information, 2020b).

Flood of March 2019.- The flood of March 2019 was the greatest flood on record in the Little Sioux River Basin (USGS, 2020a). Flooding was a result of rapid snowmelt (1-3 in. snow water equivalent) and 1-3 in. of rain that fell over much of the basin (1.27 in. at Spencer and 1.04 in. $4 \mathrm{mi}$ east of Sioux Rapids) on March 13-14 (NOAA, 2020a).

Record peak discharges of $58,400 \mathrm{ft}^{3} / \mathrm{s}$ (AEP estimate between 0.2 and 0.5 percent), 30,600 ft $\mathrm{ft}^{3} / \mathrm{s}$ (AEP estimate between 2 and 4 percent), and 26,400 ft $3 / \mathrm{s}$ (AEP estimate between 1 and 2 percent) were recorded at the USGS streamgages Little Sioux River near Turin, Little Sioux River at Correctionville, and Little Sioux River at Linn Grove, respectively (USGS, 2020a; table 1). Widespread damage across eastern and western Iowa resulted in Presidential or State disaster declarations for all counties in the Little Sioux River Basin (FEMA, 2019; Iowa Department of Homeland Security and Emergency Management, 2020). 


\section{Floods of June-July 2018}

Based on annual maximum peak discharge data available through water year 2019, the June-July 2018 flood is the fifth largest flood on record at the USGS streamgage Floyd River at Alton, the 16th largest flood at the USGS streamgage Floyd River at James; the fifth largest flood at the USGS streamgage Little Sioux River at Linn Grove, the 12th largest flood at the USGS streamgage Little Sioux River at Correctionville, and the 18th largest flood at the USGS streamgage Little Sioux River near Turin (USGS, 2020a).

\section{Storm Description}

Sustained rainfall that fell within the Floyd River Basin on June 14-21, 2018, resulted in the June 21-24, 2018, flooding. Within the Floyd River Basin, rainfall totals from NOAA stations from June 14 to 21 preceding flooding were 3.01 in. at Le Mars (USC00134735), 4.50 in. at Orange City (USC00136273), and 7.44 in. at Sheldon (USC00137594; fig. 1). Total estimated precipitation from June 14 to 21 for the Floyd River Basin is shown in figure 1. This estimated precipitation was based on the NWS Advanced Hydrologic Prediction Service quantitative precipitation estimates (NWS, 2020a). The floods were part of an exceptionally wet June in Iowa: the 10 th wettest on record. The average statewide rainfall for June in 2018 was $7.55 \mathrm{in}$. compared to the average value of $4.86 \mathrm{in}$. for the period of 1981 to 2000 (Midwestern Regional Climate Center [MRCC], 2019), and 2018 was one of the wettest years on record for Iowa with an average statewide rainfall of 45.08 in., second only to 1993 , which had an average statewide rainfall of 47.88 in. (MRCC, 2019). Within the Floyd River Basin, 2018 was the wettest year on record in Sheldon (50.12 in.) and Orange City (45.55 in.; MRCC, 2019).

Within the Little Sioux River Basin, rainfall amounts for the 2-week period from June 14 to 27 preceding the June 27-July 1, 2018, flooding were 11.29 in. at Lake Park (USC00134561; about $15 \mathrm{mi}$ north of the profiled reach), 12.95 in. at Milford (USC00135493; about $10 \mathrm{mi}$ north of the profiled reach), 5.56 in. at Spencer (USW00014972), 7.71 in. at Sioux Rapids (USC00137726), and 6.13 in. at Cherokee (USC00131442; MRCC, 2019; fig. 2). Total estimated precipitation for the Little Sioux River Basin from June 14 to 27 based on the NWS Advanced Hydrologic Prediction Service quantitative precipitation estimates is shown in figure 2 (NWS, 2020a). Within the Little Sioux River Basin, the wettest year on record was in 2018 at Milford (51.37 in.) and Sioux Rapids (46.55 in.; MRCC, 2019).

\section{Flood Description}

Sustained rainfall caused widespread flooding throughout five counties in northwestern Iowa. The NWS issued flood warnings on June 21 for the Big Sioux River (not shown), Little Sioux River, Floyd River, Rock River (not shown), and
Ocheyedan River near Spencer (Des Moines Register, 2018) and issued a flash flood warning for Sioux City, South Sioux City (not shown), North Sioux City (not shown), and Le Mars on June 24, 2018 (Dockter, 2018). Flooding in the two river basins resulted in major disaster declarations being issued in Buena Vista, Cherokee, Clay, O'Brien, and Sioux Counties (FEMA, 2018).

\section{Floyd River Basin}

The June-July 2018 flood caused flooding within the Floyd River Basin on June 21-24, 2018, at two USGS streamgages (fig. 1). A maximum peak discharge of $14,300 \mathrm{ft}^{3} / \mathrm{s}$ (AEP estimate between 4 and 10 percent) was recorded at the USGS streamgage Floyd River at Alton (fig. 3 and table 1), and a maximum peak discharge of $9,180 \mathrm{ft}^{3} / \mathrm{s}$ (AEP estimate greater than 10 percent) was recorded at the USGS streamgage Floyd River at James (USGS, 2020a; table 1).

Flood waters from the Floyd River caused closures of Highway 60 north of Seney (not shown), Mahogany Avenue north of Le Mars Municipal Park, 160th Street, and County Road C16 north of Seney (Van Buskirk, 2018). Estimated countywide damages from severe storms, tornadoes, straightline winds, and flooding on June 6-July 2 were about $\$ 1.6$ million in O'Brien County and $\$ 930,000$ in Sioux County, and estimated countywide damages to public infrastructure were about $\$ 1.3$ million in O'Brien County and \$530,000 in Sioux County (Lucinda Parker, Iowa Department of Homeland Security and Emergency Management, written commun., 2019). In addition to damages to public infrastructure, estimated countywide damages to roads and bridges were about $\$ 190,000$ in O'Brien County and $\$ 220,000$ in Sioux County (Lucinda Parker, Iowa Department of Homeland Security and Emergency Management, written commun., 2019).

\section{Little Sioux River Basin}

The June-July 2018 flood caused more severe flooding within the Little Sioux River Basin on June 27-July 1, 2018, at three USGS streamgages (fig. 2). A maximum peak discharge of 16,300 ft $3 / \mathrm{s}$ (AEP estimate between 4 and 10 percent) was recorded at the USGS streamgage Little Sioux River at Linn Grove (fig. 4 and table 1). Maximum peak discharges of $18,700 \mathrm{ft}^{3} / \mathrm{s}$ (AEP estimate greater than 10 percent) and 20,000 ft $3 / \mathrm{s}$ (AEP estimate greater than 10 percent) were recorded at the USGS streamgages Little Sioux River at Correctionville and Little Sioux River near Turin, respectively (USGS, 2020a; table 1). The peak discharges at these USGS streamgages were determined from rating curves that were verified by discharge measurements made near the time of occurrence of the respective peaks.

In Cherokee, Iowa, flood waters from the Little Sioux River caused closures on East Main Street, the Highway 59 bridge, East Beech Street, West Beech Street, and Maple Street 


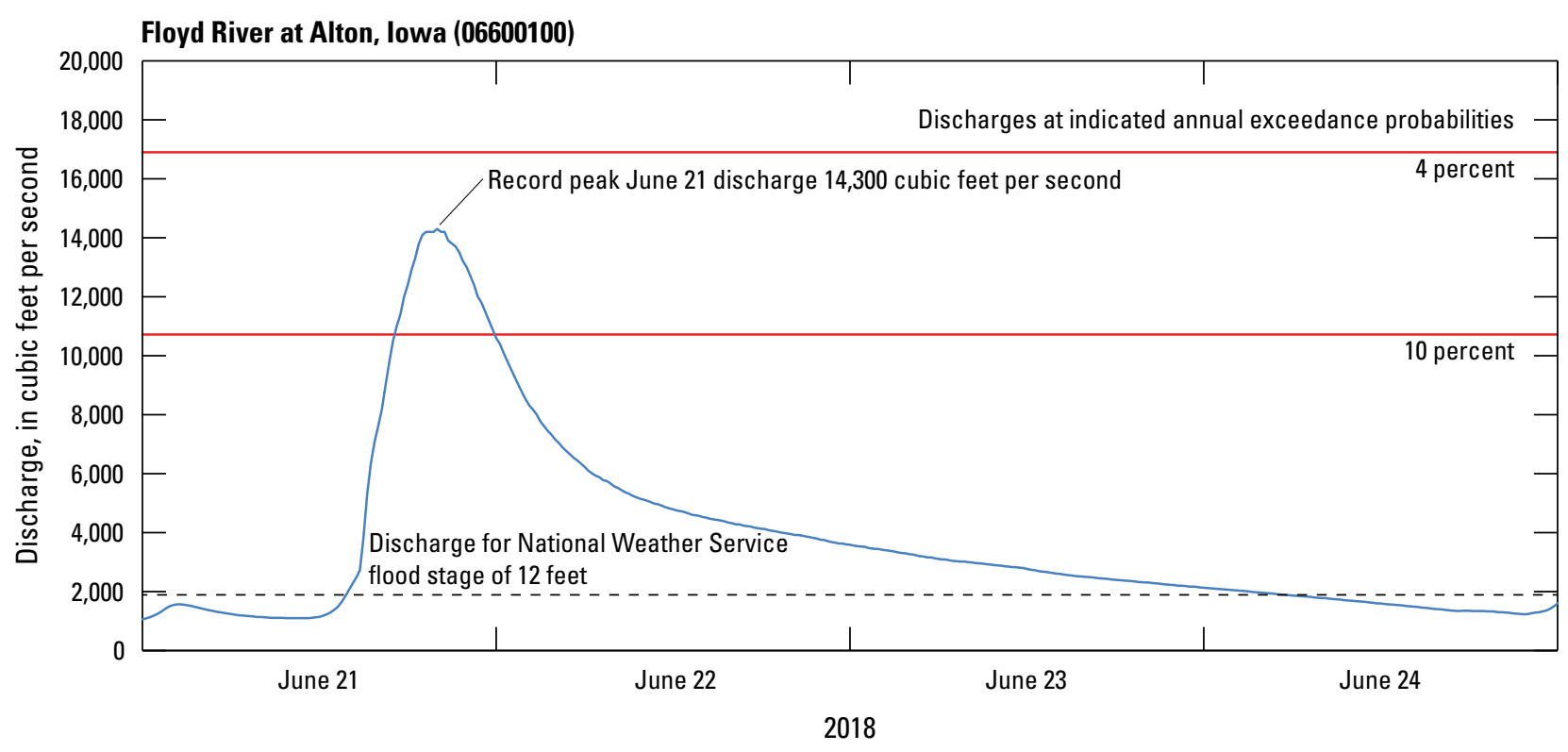

Figure 3. Discharge hydrograph for June 21-24, 2018, with annual exceedance probabilities annotated for the U.S. Geological Survey streamgage Floyd River at Alton, lowa.

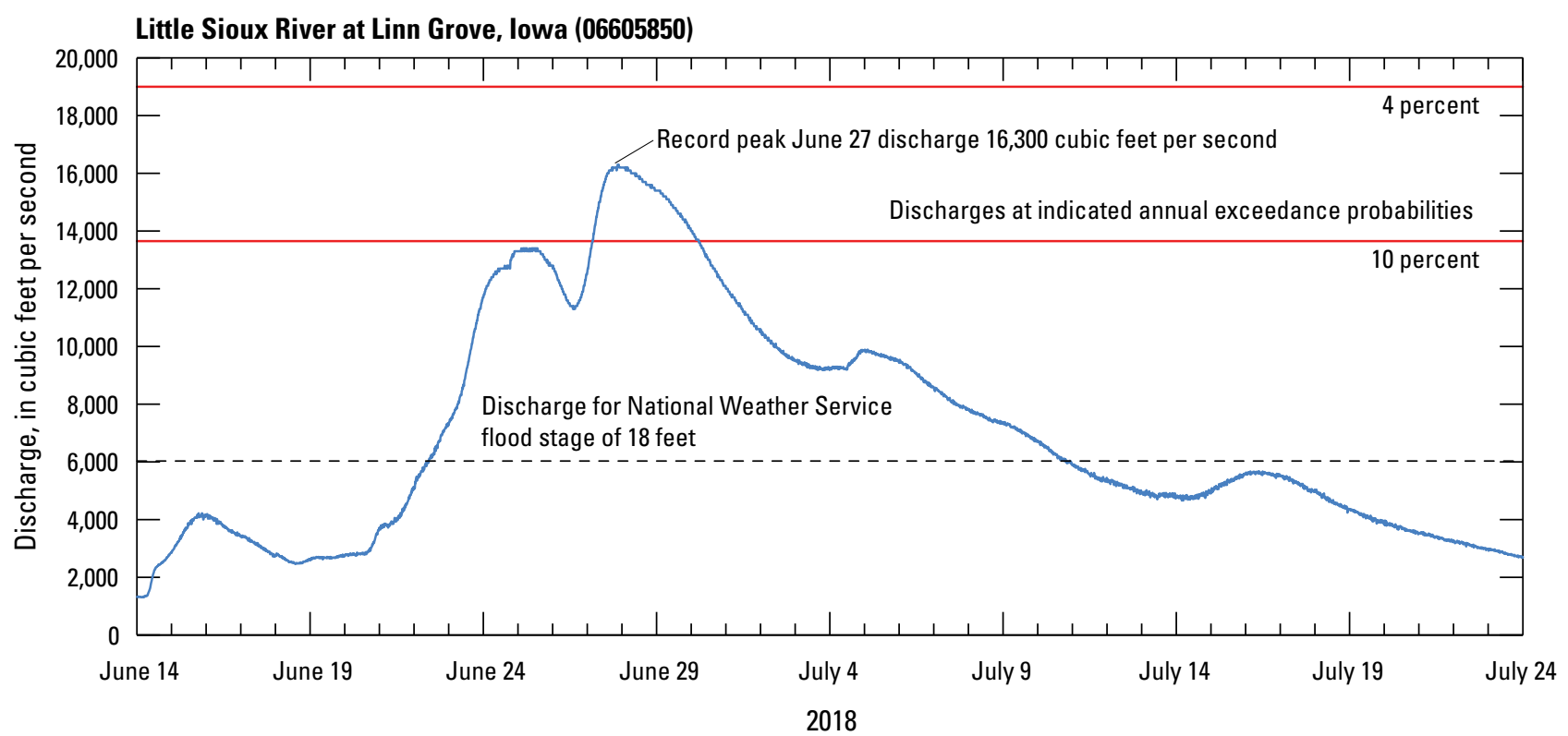

Figure 4. Discharge hydrograph for June 14-July 24, 2018, with annual exceedance probabilities annotated for the U.S. Geological Survey streamgage Little Sioux River at Linn Grove, lowa.

(not shown; Chronicle Times, 2018). Flood waters from the Little Sioux River caused closures of U.S. Highway 18 from Spencer to Dickens (not shown) and about 30 stretches of road throughout Clay County (Harguth, 2018). Estimated countywide damages from severe storms, tornadoes, straight-line winds, and flooding for June 6-July 2 were about $\$ 420,000$ in Buena Vista County, $\$ 1.3$ million in Cherokee County, $\$ 410,000$ in Clay County, and \$1.6 million in O’Brien County, and estimated countywide damages to public infrastructure were about \$130,000 in Buena Vista County, \$1.3 million in Cherokee County, $\$ 160,000$ in Clay County, and \$1.3 million in O'Brien County (Lucinda Parker, Iowa Department of Homeland Security and Emergency Management, written commun., 2019). In addition to damages to public infrastructure, estimated countywide damages to roads and bridges were about \$130,000 in Buena Vista County, $\$ 10,000$ in Cherokee County, $\$ 190,000$ in Clay County, and $\$ 190,000$ 
in O'Brien County (Lucinda Parker, Iowa Department of Homeland Security and Emergency Management, written commun., 2019).

\section{Annual Exceedance Probabilities}

The AEP is an estimate of the likelihood of a flood of specific magnitude occurring in any one year, and the AEP range expresses the uncertainty of estimating precise exceedance probabilities. The reporting ranges are greater than 10 percent, $4-10$ percent, $2-4$ percent, $1-2$ percent, $0.5-1$ percent, $0.2-0.5$ percent, and less than 0.2 percent. The range is determined by the estimated AEP discharges that bracket the observed flood-peak discharge. If the observed peak discharge is the same value as an estimated AEP discharge, the lower AEP range is used.

At-site AEPs are computed based on the annual maximum peak discharge data available at a streamgage. As additional annual maximum peak discharge data are collected at a streamgage, AEP estimates can change. As more years of record become available, the associated AEP estimates for a streamgage will become more statistically reliable. A minimum of 10 years of record is required to compute AEP estimates at a streamgage (Eash and others, 2013).

Annual maximum peak discharge data available through water year 2019 were used to calculate the AEP discharge estimates described in this report. The estimated 10- and 4-percent AEP discharges at the USGS streamgages Floyd River at Alton and Little Sioux River at Linn Grove are represented as horizontal lines (figs. 3 and 4); the AEP ranges are the areas between the lines. The probability discharges for the USGS streamgage Little Sioux River at Correctionville were calculated as weighted independent estimates of the at-site flood-frequency quantiles with quantile estimates obtained by regional regression equations following guidelines in appendix 9 of Bulletin 17C (England and others, 2018) and are available as a USGS data release (O'Shea and Fiala, 2021). The probability discharges for the seven other streamgages in the Floyd and Little Sioux River Basins included in table 1 were calculated following the same guidelines and are available as a USGS data release (Fiala and O'Shea, 2022).

Exceedance probabilities were formerly reported as flood probabilities, or flood-recurrence intervals, expressed in years. A 1-percent exceedance probability discharge is the same as the 100-year recurrence-interval flood discharge. Because of confusion caused over the years by two or more " 100 -year floods" occurring in a period of much less than 100 years, the scientific and engineering community has begun expressing the annual likelihood of occurrence of flood discharges as a probability (Holmes and Dinicola, 2010). Percentage probability is the inverse of the recurrence interval multiplied by 100 . Selected AEPs and equivalent flood-recurrence intervals are listed in table 2.

For information purposes, the NWS designated flood stages also are shown on the hydrographs (figs. 3 and 4). The flood stages represent "an established gage height for a given location at which a rise in water surface level begins to create a hazard to lives, property, or commerce" (NWS, 2019, p. 3). To place the NWS flood stages in figures 3 and 4, the respective stage-discharge rating curve in use at the two streamgages for the June 21-27 floods was used to estimate the corresponding discharge. Stage-discharge rating curves for USGS streamgages are developed by physically measuring the flow of the river at a wide range of stages, allowing each measurement of stage to have a corresponding measurement of discharge. The stage-discharge relation at a streamgage can change over time because of natural processes such as scour and fill (USGS, 2021). The most up-to-date stage-discharge rating curve for a USGS streamgage can be accessed online via the USGS rating depot (https://waterwatch.usgs.gov/?id= mkrc). At the USGS streamgage Floyd River at Alton, the NWS flood stage is $12 \mathrm{ft}$ (NWS, 2020b), and the discharge is $1,890 \mathrm{ft}^{3} / \mathrm{s}$ (USGS, 2020b). At the USGS streamgage Little Sioux River at Linn Grove, the NWS flood stage is $18 \mathrm{ft}$ (NWS, 2020c), and the discharge is $6,030 \mathrm{ft}^{3} / \mathrm{s}$ (USGS, 2020c).

Table 2. Annual exceedance probability and equivalent flood-recurrence interval for selected probabilities.

\begin{tabular}{cc}
\hline $\begin{array}{c}\text { Annual exceedance probability } \\
\text { (percent) }\end{array}$ & $\begin{array}{c}\text { Flood-recurrence interval } \\
\text { (years) }\end{array}$ \\
\hline 20 & 5 \\
10 & 10 \\
4 & 25 \\
2 & 50 \\
1 & 100 \\
0.5 & 200 \\
0.2 & 500 \\
\hline
\end{tabular}




\section{Flood Profile}

The USGS located and surveyed the elevations of HWMs at 19 locations along the Floyd River and 22 locations along the Little Sioux River to develop flood profiles (figs. 1 and 2; tables 3 and 4). The profiled reach of the Floyd River is 52.5 river miles from State Highway 3 at Le Mars to U.S. Highway 18 at Sheldon, Iowa. The profiled reach of the Little Sioux River is 101 river miles from U.S. Highway 59 at Cherokee to U.S. Highway 18 north of Spencer, Iowa. The HWM locations include U.S. and State numbered highway bridges and several county and local road bridges within the profiled reach of each basin.
The HWMs, which consisted of mud, seed, debris, and stain lines, were located and marked by USGS field personnel within 1 week of the flood peaks. Information about individual HWMs, including the type of HWM, are available on the USGS Flood Event Viewer online data portal (described in the "Flood Event Viewer" section). Multiple HWMs were identified on the upstream and downstream sides of the bridges. The upstream marks were upstream from the bridge a distance of at least one width of the bridge opening to avoid drawdown zone effects from channel contraction, and the downstream marks were immediately downstream from the bridge (Matthai, 1967). During August 17-22, 2018, the HWMs were surveyed to either a temporary bench mark or an Iowa Department of Transportation established bench mark at each location. Bridge deck, low-bridge chord, and low-flow

Table 3. Locations and elevations of high-water marks used in the Floyd River flood profile, flood of June 21-24, 2018, northwestern lowa.

[HWM, high-water mark; NAVD 88, North American Vertical Datum of 1988; NW, Northwest; ND, not determined; USGS, U.S. Geological Survey; E, East; St, Street; UN, unavailable; NE, Northeast; NGVD 29, National Geodetic Vertical Datum of 1929]

\begin{tabular}{clcc}
\hline $\begin{array}{c}\text { Distance } \\
\text { from mouth } \\
\text { (river miles) }\end{array}$ & \multicolumn{1}{c}{ Location } & $\begin{array}{c}\text { Downstream HWM } \\
\text { (feet above NAVD 88) }\end{array}$ & $\begin{array}{c}\text { Upstream HWM } \\
\text { (feet above NAVD 88) }\end{array}$ \\
\hline 31.43 & Highway 3, Le Mars & $1,199.99$ & $1,200.35$ \\
\hline 32.37 & 5th Avenue NW (Business Highway 75), Le Mars & $1,204.59$ & $1,204.90$ \\
\hline 32.92 & Mouth of Willow Creek 1 & ND & ND \\
\hline 34.67 & 160th Street, north of Le Mars & $1,210.12$ & $1,212.76$ \\
\hline 36.39 & 150th Street, north of Le Mars & $1,219.10$ & $1,220.18$ \\
\hline 38.49 & 140th Street (Meadowlark Avenue), north of Le Mars & $1,226.69$ & $1,227.85$ \\
\hline 40.38 & County Road C16 (130th Street), north of Le Mars & $1,233.57$ & $1,234.28$ \\
\hline 43.79 & County Road C12 (110th Street), north of Le Mars & $1,247.82$ & $1,249.49$ \\
\hline 49.94 & 490th Street, south of Alton & $1,271.09$ & $1,271.84$ \\
\hline 54.62 & Highway 60, south of Alton & $1,286.42$ & $1,288.89$ \\
\hline 55.47 & USGS streamgage 06600100, south of E Division St, at Alton & $1,290.88$ & ND \\
\hline 56.99 & Highway 10 (450th Street), Alton & UN & UN \\
\hline 58.12 & Kennedy Avenue, north of Alton & $1,297.81$ & $1,298.93$ \\
\hline 60.48 & Kingbird Avenue (County Road L14), north of Alton & $1,305.76$ & ND \\
\hline 63.64 & 430th Street, north of Alton & ND & $1,313.96$ \\
\hline 68.07 & 410th Street, south of Hospers & $1,324.06$ & $1,324.70$ \\
\hline 70.47 & 400th Street (County Road B40), Hospers & $1,330.35$ & UN \\
\hline 72.24 & Mouth of Willow Creek 2 & ND & ND \\
\hline 74.28 & 380th Street (20th St NE), north of Hospers & $1,340.14$ & $1,340.65$ \\
\hline 78.11 & 360th Street, south of Sheldon & $1,351.96$ & $1,354.38$ \\
\hline 79.42 & 350th Street, south of Sheldon & $1,358.07$ & $1,358.89$ \\
\hline 81.03 & Mouth of Little Floyd & ND & ND \\
\hline 82.35 & 330th Street, Sheldon & $1,371.49$ & $1,373.30$ \\
\hline
\end{tabular}

${ }^{1}$ HWM derived from recorded gage height at USGS streamgage 06600100, converted from NGVD 29 to NAVD 88 using the National Geodetic Survey's Coordinate Conversion and Transformation Tool (https://www.ngs.noaa.gov/NCAT/). 
Table 4. Locations and elevations of high-water marks used in the Little Sioux River flood profile, flood of June 27-July 1, 2018, northwestern lowa.

[HWM, high-water mark; NAVD 88, North American Vertical Datum of 1988; S, South; E, East; ND, not determined; USGS, U.S. Geological Survey; St, Street; W, West; NGVD 29, National Geodetic Vertical Datum of 1929]

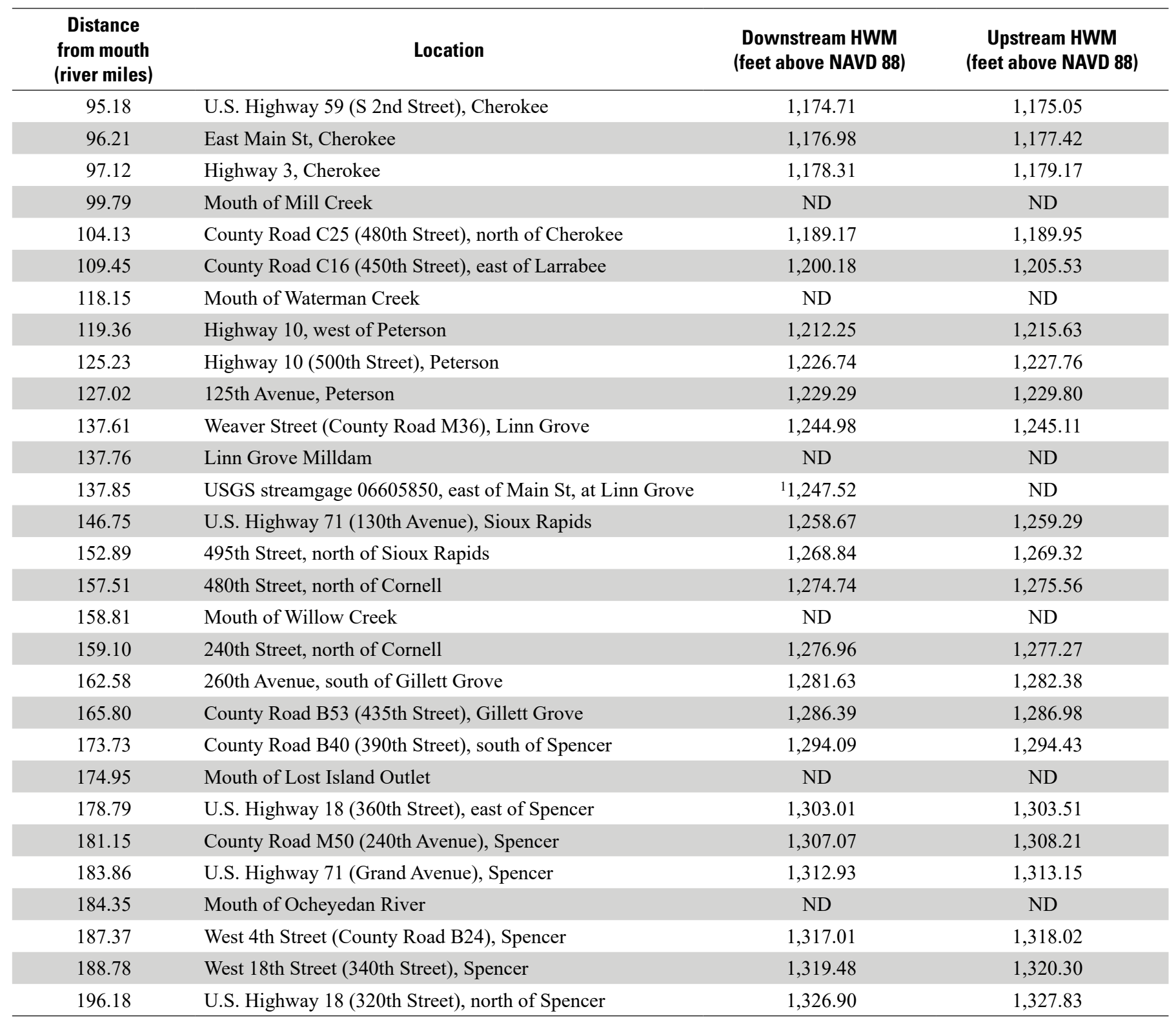

${ }^{1}$ HWM derived from recorded gage height at USGS streamgage 06605850, converted from NGVD 29 to NAVD 88 using the National Geodetic Survey's Coordinate Conversion and Transformation Tool (https://www.ngs.noaa.gov/NCAT/).

reference-point elevations also were measured with respect to the bench marks. The low-flow reference points, described in appendix 1, were established so that water-surface elevations could be measured during a period when the discharge was not directly affected by precipitation. All elevations are published in the North American Vertical Datum of 1988 and are listed in appendix 1 .
The locations of HWMs were described in river miles with river mile zero at the mouth of the Floyd or Little Sioux Rivers at the Missouri River and river miles increasing in the upstream direction. The distances to HWMs were determined using a geographic information system software using the USGS National Hydrography Dataset data (USGS, 2019). The HWM locations and elevations for the Little Sioux and Floyd 


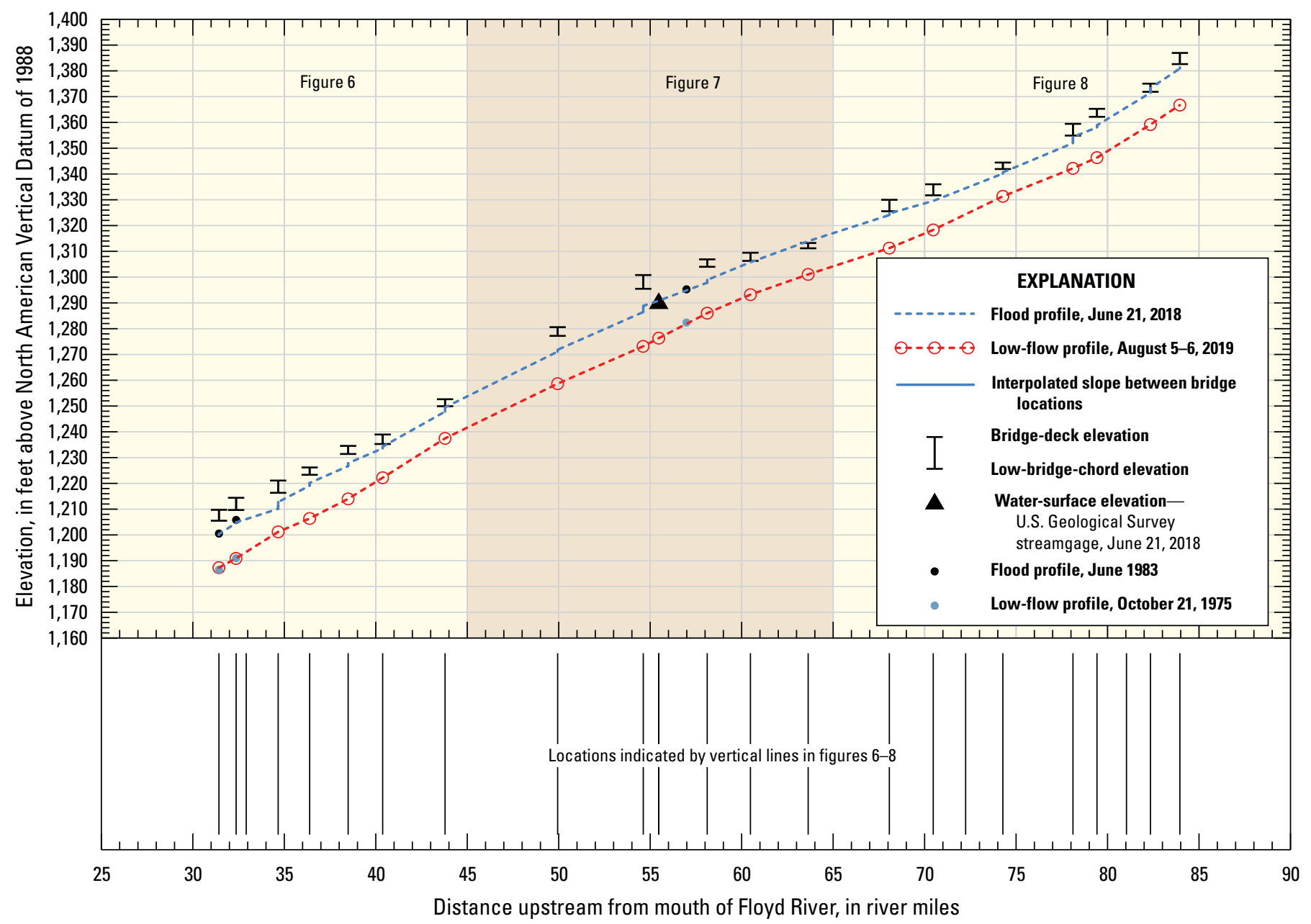

Figure 5. Flood profile of Floyd River, river miles 31.4-84, June 21-24, 2018.

Rivers are listed in tables 3 and 4 and profiled in figures 5-12 and are an average of multiple upstream and downstream HWMs measured at each location.

The HWMs along the Floyd and Little Sioux Rivers are plotted in flood profiles in figures 5 and 9 , respectively, and the profiles are expanded in figures 6-8 and 10-12, where the locations are annotated. The profile lines connecting the HWMs in the figures approximate the flood elevation between marks. Only bridges where HWMs were measured are shown in the figures. Bridges are symbolized by an I-beam symbol, where the bottom flange represents the lowest elevation of the low-bridge chord and the top flange represents the elevation of the bridge deck. Profile lines do not account for any intermediate features that could affect flood elevation such as channel morphology or bridges and dams where HWMs were not measured. The low-flow line also is a straight-line interpolation meant to estimate the water surface between HWM locations. The vertical lines along the bottom of the figures also show locations of roads and bridges where HWMs were measured. Selected landmarks also are shown (figs. 5-12).
The June 21-24, 2018, flood along the Floyd River is profiled from State Highway 3 in Le Mars upstream to U.S. Highway 18 in Sheldon (fig. 5). The 52.5-mi river reach is shown in figure 5, and the 19 stream sites where HWMs were measured are listed in table 3. A flood profile measured in June 1983 (Heinitz, 1986) and low-flow profile measured on October 21, 1975 (Heinitz, 1986), are shown in figures 5-7. A low-flow profile measured on August 5-6, 2019, is shown in figures 5-8.

The June 27-July 1, 2018, flood along the Little Sioux River is profiled from U.S. Highway 59 in Cherokee upstream to U.S. Highway 18 north of Spencer (fig. 9). The 101-mi river reach is shown in figure 9 , and the 22 stream sites where HWMs were measured are listed in table 4. A flood profile measured on April 8, 1965 (Schwob, 1966); low-flow profile measured on October 1, 1963 (Schwob, 1966); and a low-flow profile measured on August 6-7, 2019, are shown in figures 9-12. A low-flow profile measured on November 6, 1962, is also shown in figures 9 and 12. 


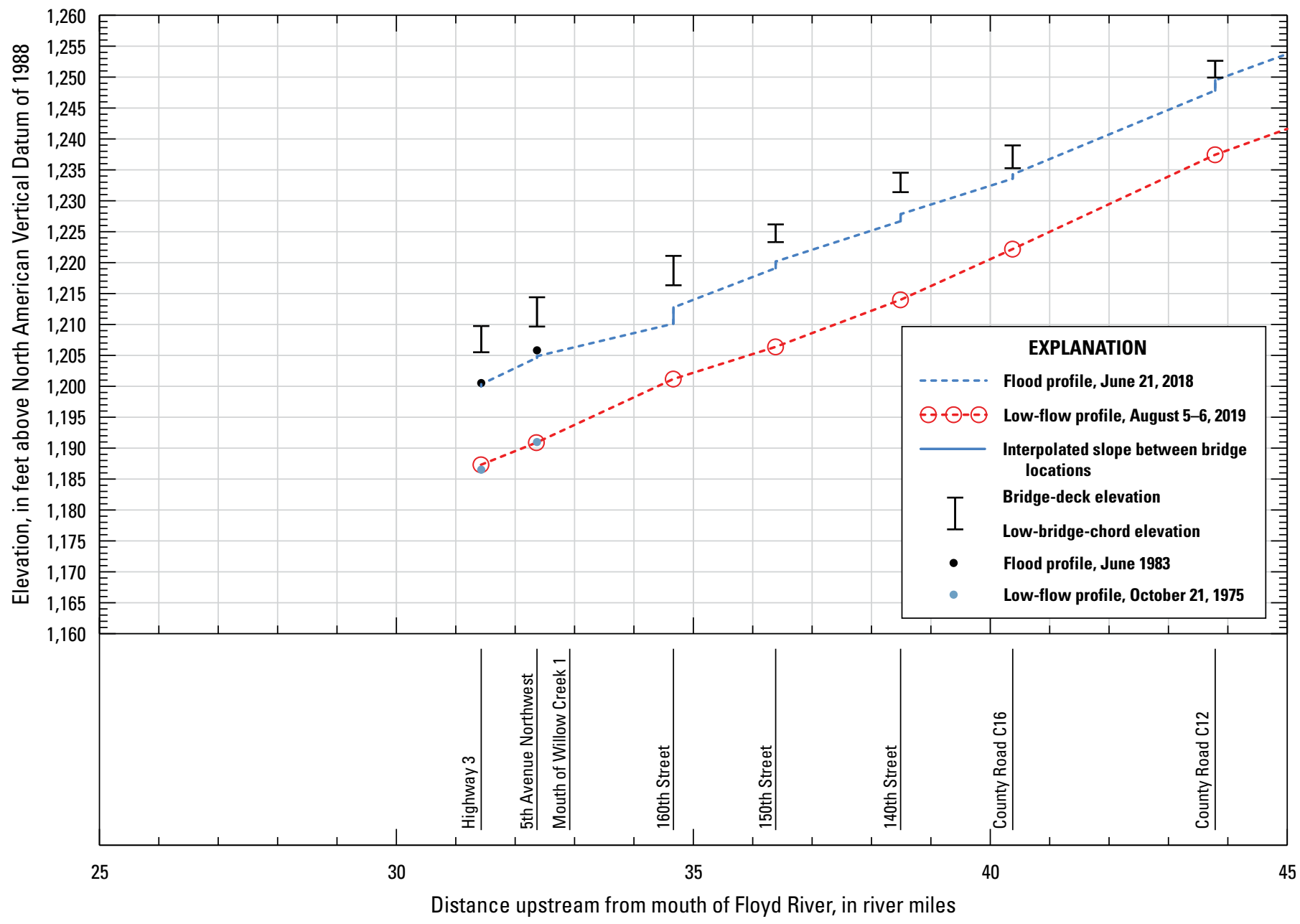

Figure 6. Flood profile of Floyd River, river miles 31.4-45, June 21-24, 2018. 


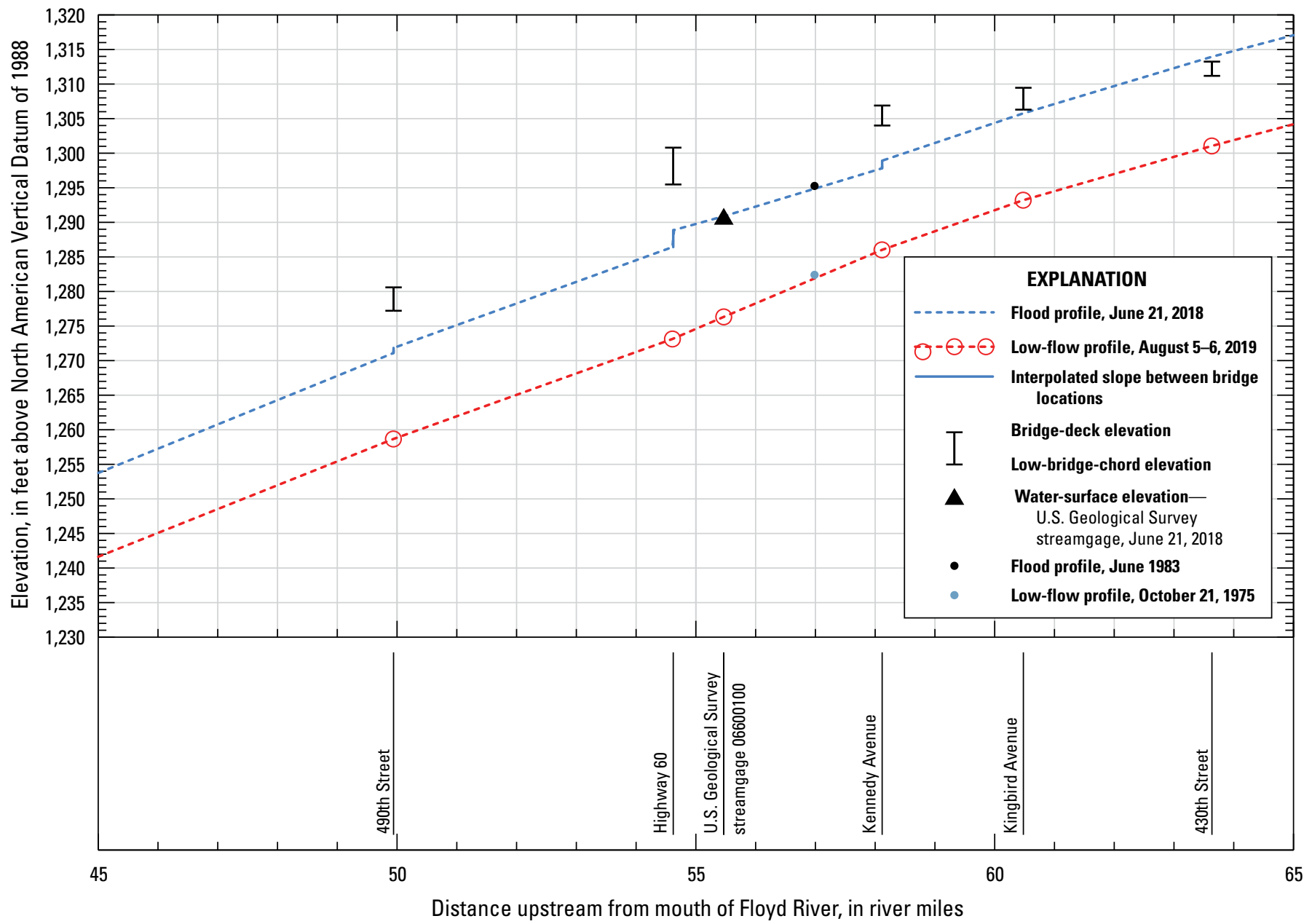

Figure 7. Flood profile of Floyd River, river miles 45-65, June 21-24, 2018. 


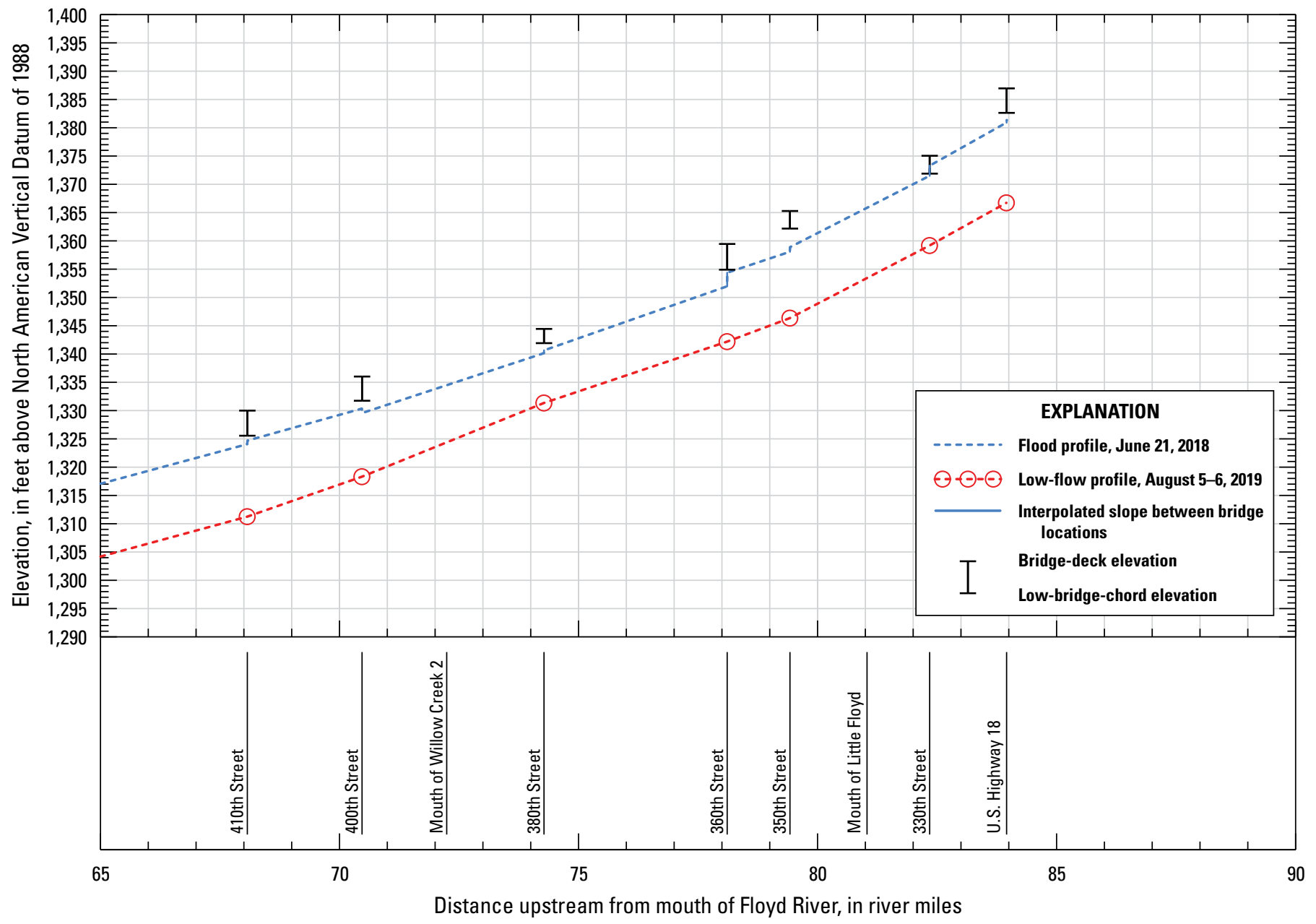

Figure 8. Flood profile of Floyd River, river miles 65-84, June 21-24, 2018. 


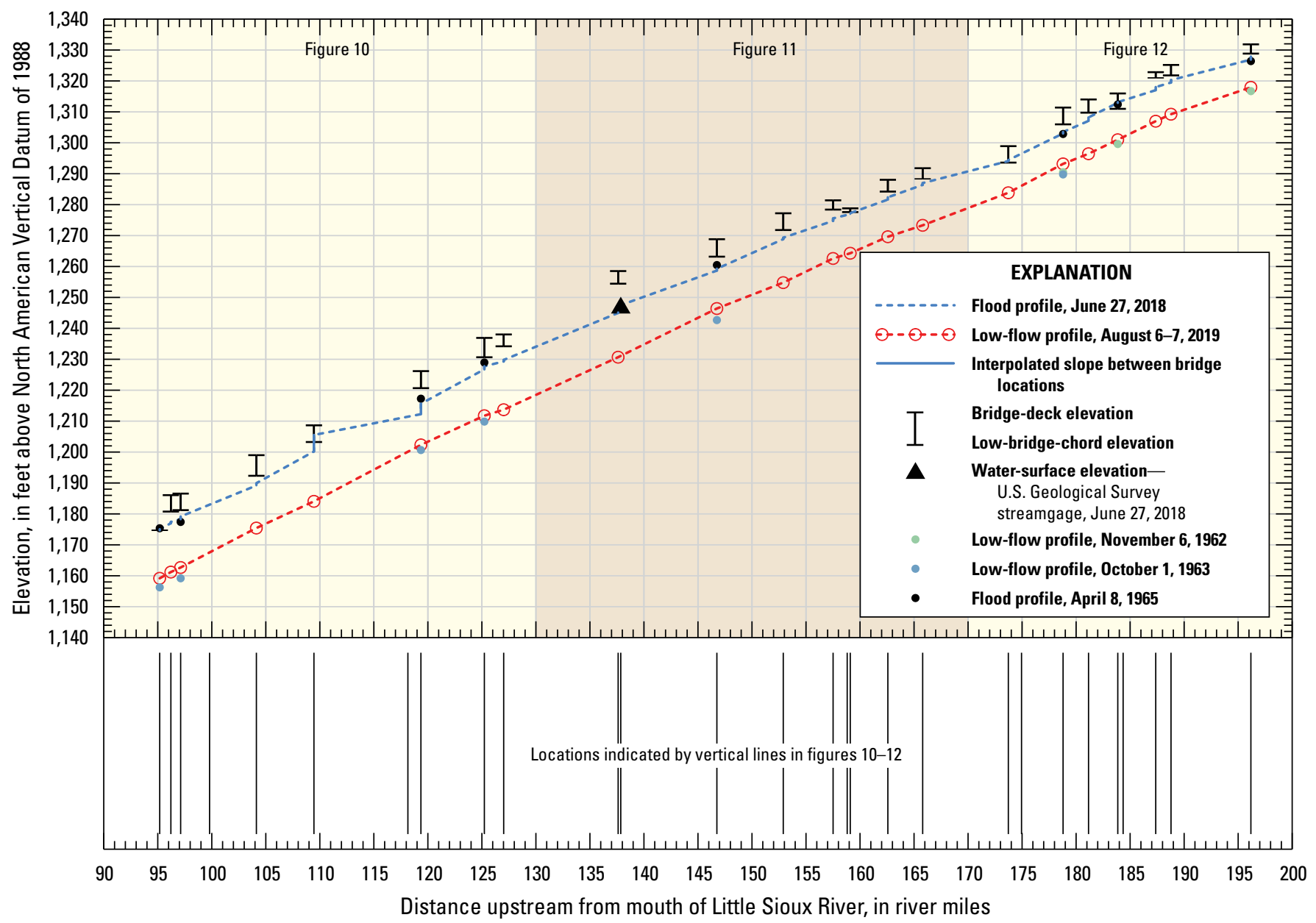

Figure 9. Flood profile of Little Sioux River, river miles 95.2-196.2, June 27-July 1, 2018. 


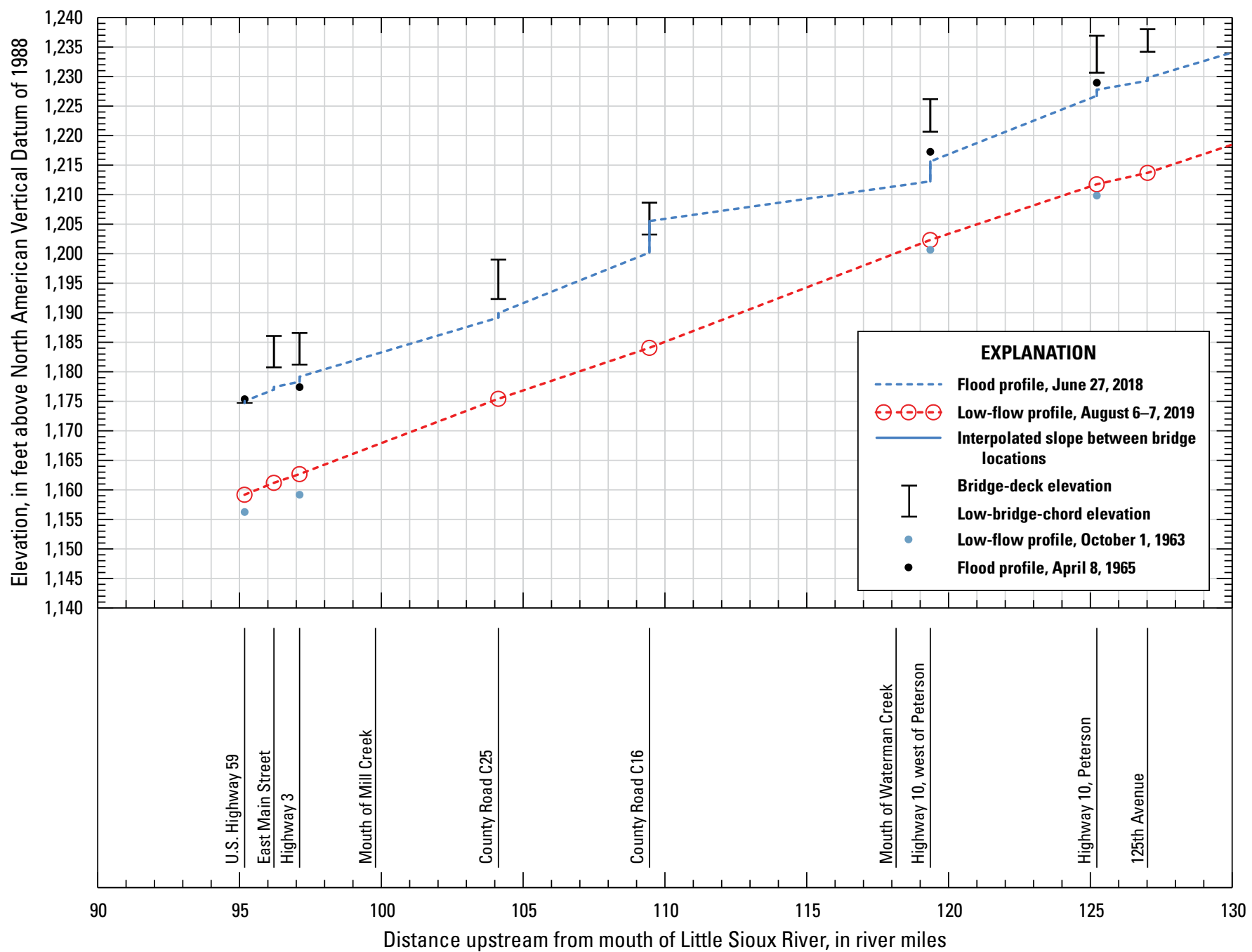

Figure 10. Flood profile of Little Sioux River, river miles 95.2-130, June 27-July 1, 2018. 


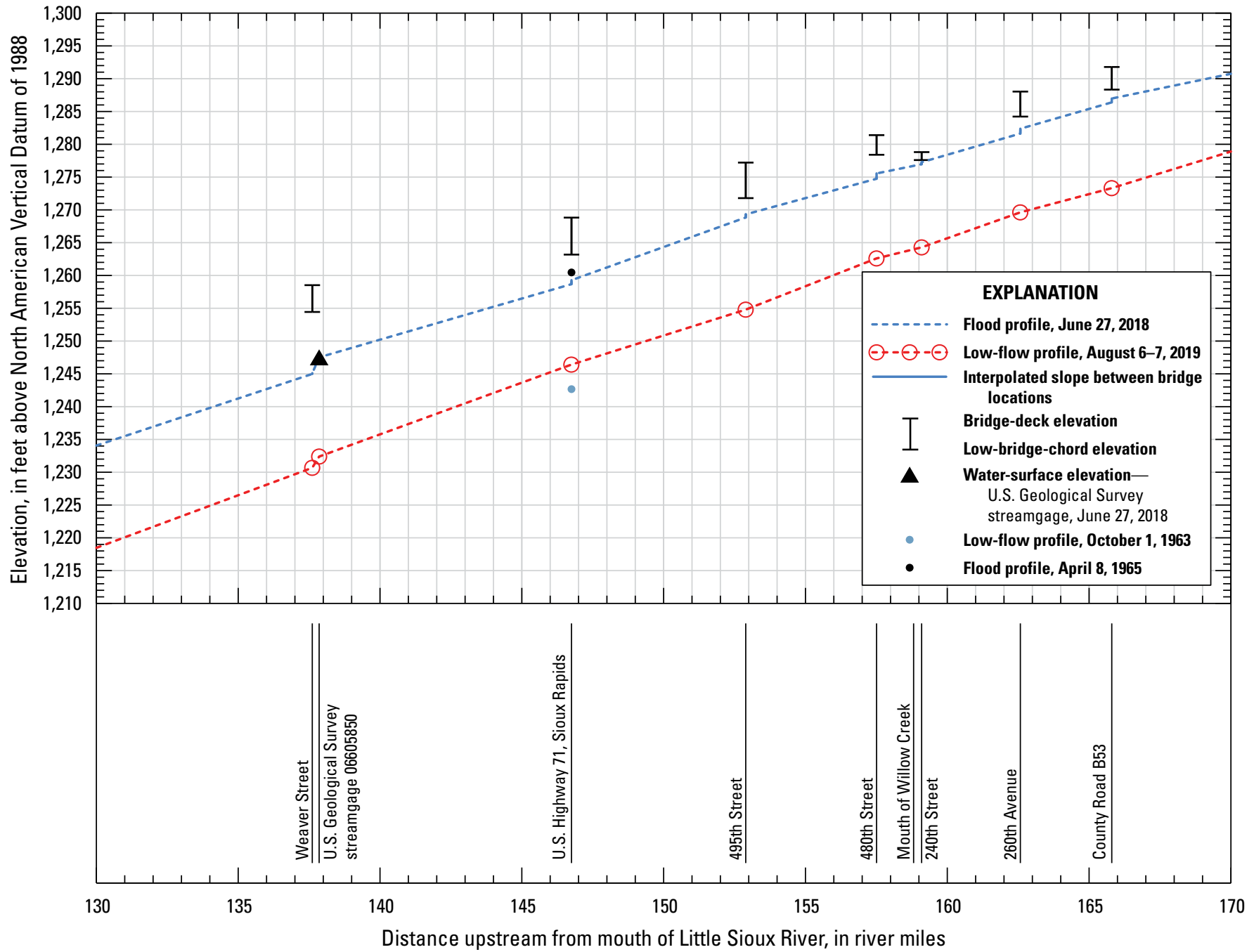

Figure 11. Flood profile of Little Sioux River, river miles 130-170, June 27-July 1, 2018. 


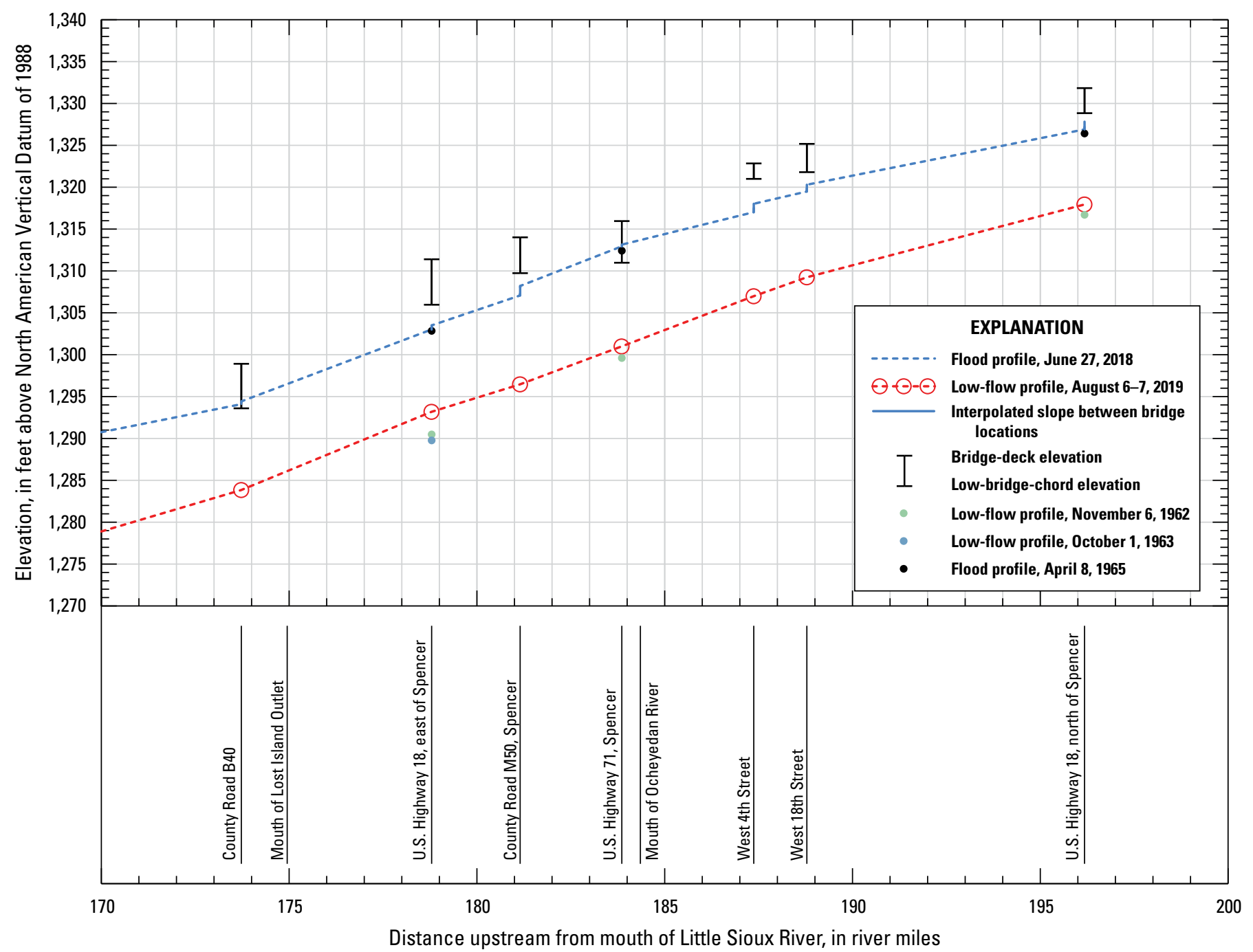

Figure 12. Flood profile of Little Sioux River, river miles 170-196.2, June 27-July 1, 2018.

\section{Flood Event Viewer}

The HWM elevations collected for this report have been incorporated into the USGS Flood Event Viewer online data portal (https://stn.wim.usgs.gov/FEV/). Users can type in "Iowa June-July 2018 flood" in the search box to view the results. The USGS plays an important role in the collection and delivery of data resulting from coastal and inland flooding events. The data collected from surveyed HWM elevations are stored in the Short-Term Network database (https://stn.wim. usgs.gov/STNWeb/). The USGS developed the Short-Term Network database, and an accompanying set of tools, to facilitate the collection and dissemination of event-based flood data. Data can be viewed in the Flood Event Viewer, a mapcentric data portal that allows users to explore and download sensor data and HWM records for any event in the Short-Term Network database, including historical high-water events dating back more than 40 years (Jenter and others, 2017).

\section{Summary}

The Floyd River and Little Sioux River Basins in northwestern Iowa flooded on June 21-July 1, 2018, after sustained rainfall on June 14-27, 2018. Within the Floyd River Basin, rainfall totals from June 14 to 21 preceding flooding were 3.01 inches (in.) at Le Mars, 4.50 in. at Orange City, and 7.44 in. at Sheldon. Within the Little Sioux River Basin, rainfall amounts for the 2-week period from June 14 to 27 preceding flooding were 11.29 in. at Lake Park (about 15 miles [mi] north of the profiled reach), 12.95 in. at Milford (about $10 \mathrm{mi}$ north of the profiled reach), $5.56 \mathrm{in}$. at Spencer, $7.71 \mathrm{in.}$ at Sioux Rapids, and 6.13 in. at Cherokee.

Flooding in the Floyd River Basin resulted in a maximum peak discharge of 14,300 cubic feet per second $\left(\mathrm{ft}^{3} / \mathrm{s}\right.$; annual exceedance probability [AEP] estimate between 4 and 10 percent) at the U.S. Geological Survey (USGS) streamgage Floyd River at Alton, Iowa (06600100), and a maximum peak discharge of $9,180 \mathrm{ft}^{3} / \mathrm{s}$ (AEP estimate greater than 
10 percent) at the USGS streamgage Floyd River at James, Iowa (06600500). Flooding in the Little Sioux River Basin resulted in a maximum peak discharge of $16,300 \mathrm{ft}^{3} / \mathrm{s}$ (AEP estimate between 4 and 10 percent) at the USGS streamgage Little Sioux River at Linn Grove, Iowa (06605850). Maximum peak discharges of $18,700 \mathrm{ft}^{3} / \mathrm{s}$ (AEP estimate greater than 10 percent) and $20,000 \mathrm{ft}^{3} / \mathrm{s}$ (AEP estimate greater than 10 percent) were recorded at the USGS streamgages Little Sioux River at Correctionville, Iowa (06606600), and Little Sioux River near Turin, Iowa (06607500), respectively. Highwater mark elevations were surveyed at 19 locations along the Floyd River and 22 locations along the Little Sioux River to develop 2 flood profiles: a 52.5-mi profile along the Floyd River from State Highway 3 at Le Mars to U.S. Highway 18 at Sheldon that includes the USGS streamgage Floyd River at Alton and a 101-mi profile along the Little Sioux River from U.S. Highway 59 at Cherokee to U.S. Highway 18 north of Spencer that includes the USGS streamgage Little Sioux River at Linn Grove.

\section{References Cited}

Chronicle Times, 2018, Little Sioux River flood update: Chronicle Times, June 27, 2018, accessed October 28, 2019, at https://www.chronicletimes.com/story/2533648.html.

Des Moines Register, 2018, Iowa flooding-High waters close parks and roads: Des Moines Register, June 21, 2018, accessed December 2, 2019, at https:/www.desmoinesreg ister.com/story/news/2018/06/21/iowa-weather-high-watersclose-parks-and-roads-cedar-river-des-moines-river-rockriver/723312002/.

Dockter, M., 2018, Updated-Heavy rainfall, swollen rivers cause flooding across Siouxland: Sioux City Journal, June 24, 2018, accessed October 28, 2019, at https://siouxcityjournal.com/news/local/updated-heavyrainfall-swollen-rivers-cause-flooding-across-siouxland/ article_848ce0c2-c145-5bd0-87e8-f032bcf30221.html.

Eash, D.A., 2014, Summary of U.S. Geological Survey reports documenting flood profiles of streams in Iowa, 1963-2012: U.S. Geological Survey Scientific Investigations Report 2014-5085, 32 p. [Also available at https://doi.org/10.3133/ sir20145085.]

Eash, D.A., Barnes, K.K., and Veilleux, A.G., 2013, Methods for estimating annual exceedance-probability discharges for streams in Iowa, based on data through water year 2010: U.S. Geological Survey Scientific Investigations Report 2013-5086, 63 p., accessed November 17, 2020, at https://doi.org/10.3133/sir20135086.
England, J.F., Jr., Cohn, T.A., Faber, B.A., Stedinger, J.R., Thomas, W.O., Jr., Veilleux, A.G., Kiang, J.E., and Mason, R.R., Jr., 2018, Guidelines for determining flood flow frequency-Bulletin 17C (ver. 1.1, May 2019): U.S. Geological Survey Techniques and Methods, book 4, chap. B5, 168 p., accessed April 21, 2020, at https://doi.org/ $10.3133 / \mathrm{tm} 4 \mathrm{~B} 5$.

Federal Emergency Management Agency [FEMA], 2018, Iowa severe storms, tornadoes, straight-line winds, and flooding (DR-4386): FEMA web page, accessed November 13, 2019, at https://www.fema.gov/disaster/4386.

Federal Emergency Management Agency [FEMA], 2019, Iowa severe storms and flooding (DR-4421-IA): FEMA web page, accessed October 14, 2020, at https://www. fema.gov/disaster/4421.

Fiala, S.G., and O'Shea, P.S., 2022, Peak-flow frequency analysis for seven selected U.S. Geological Survey streamgages in the Floyd and Little Sioux River Basins, Iowa, based on data through water year 2019: U.S. Geological Survey data release, https://doi.org/10.5066/P9V8NO0H.

Harguth, C., 2018, Several roads remain closed due to flooding: KICD, June 26, 2018, accessed October 16, 2020, at https://kicdam.com/news/170071-several-roads-remainclosed-due-to-flooding/.

Heinitz, A.J., 1986, Floods in the Floyd River basin, Iowa: U.S. Geological Survey Open-File Report 86-476, 60 p., accessed July 17, 2019, at https://doi.org/10.3133/ofr86476.

Holmes, R.R., Jr., and Dinicola, K., 2010, 100-year floodIt's all about chance: U.S. Geological Survey General Information Product 106, 1 p., accessed April 21, 2020, at https://doi.org/10.3133/gip106.

Iowa Department of Agriculture and Land Stewardship, 2018, Iowa preliminary monthly weather summary: Iowa Department of Agriculture and Land Stewardship web page, accessed December 21, 2020, at https:// iowaagriculture.gov/sites/default/files/climatology/ June2018WeatherSummary.pdf.

Iowa Department of Homeland Security and Emergency Management, 2020, Iowa disaster history: Iowa Department of Homeland Security and Emergency Management web page, accessed October 14, 2020, at https:/homelandsecurity.iowa.gov/disasters/.

Jenter, H., Koenig, T., Mason, R., and Peppler, M., 2017, Event-based flood data collection and dissemination-The USGS Flood Event Viewer and Short-Term Network database: U.S. Geological Survey memo, 1 p., accessed July 27, 2020, at https:/www.ofcm.gov/meetings/TCORF/ihc17/ Posters/P07\%20Jenter\%20STN\%20Database.pdf. 
KCCI Des Moines, 2019, Flooding causes estimated \$1.6B damage in Iowa: KCCI Des Moines, March 22, 2019, accessed October 14, 2020, at https://www.kcci.com/article/ flooding-causes-estimated-dollar16b-damage-in-iowa/ 26909750 .

Matthai, H.F., 1967, Measurement of peak discharge at width contractions by indirect methods: U.S. Geological Survey Techniques of Water-Resources Investigations, book 3, chap. A4, 44 p. [Also available at https://doi.org/10.3133/ twri03A4.]

Midwestern Regional Climate Center [MRCC], 2019, CliMATE-MRCC Application Tools Environment: MRCC digital data, accessed October 28, 2019, at https://mrcc. purdue.edu/CLIMATE/.

Multi-Resolution Land Characteristics Consortium, 2019, NLCD 2016 Land Cover, conterminous United States: Multi-Resolution Land Characteristics Consortium digital data, accessed October 7, 2020, at https://www.mrlc.gov/ data/nlcd-2016-land-cover-conus.

National Centers for Environmental Information, 2020a, Storm events database: National Centers for Environmental Information digital data, accessed November 6 , 2020, at https://www.ncdc.noaa.gov/stormevents/ eventdetails.jsp?id=782913. [Data for Plymouth County, September 18-20, 2018.]

National Centers for Environmental Information, 2020b, Storm events database: National Centers for Environmental Information digital data, accessed November 6 , 2020, at https://www.ncdc.noaa.gov/stormevents/ eventdetails.jsp?id=784763. [Data for Buena Vista County, September 18-21, 2018.]

National Oceanic and Atmospheric Administration [NOAA], 2020a, Heavy rain and snow melt create widespread flooding-March 13-14, 2019: National Oceanic and Atmospheric Administration digital data, accessed November 6, 2020, at https://www.weather.gov/fsd/ 20190314-Flooding.

National Oceanic and Atmospheric Administration [NOAA], 2020b, Widespread heavy rain, flooding, and severe storms-September 18-21, 2018: National Oceanic and Atmospheric Administration digital data, accessed November 6, 2020, at https://www.weather.gov/fsd/ 20180920-flooding-region.

National Weather Service [NWS], 1983, Storm dataJune 1983: National Weather Service, v. 6, no. 9, accessed January 28, 2022, at https:/www.ncdc.noaa.gov/IPS/ $\mathrm{sd} / \mathrm{sd} \cdot \mathrm{html}$.
National Weather Service [NWS], 2019, Water resources information on the web-A manual for users: National Weather Service, 43 p., accessed April 21, 2020, at https://www.weather.gov/media/owlie/Water\%20Resources \%20Web\%20Products\%20Manual.pdf.

National Weather Service [NWS], 2020a, Advanced Hydrologic Prediction Service-QPE-Quantitative precipitation estimates: National Weather Service digital data, accessed November 5, 2020, at https://water. weather.gov/precip/.

National Weather Service [NWS], 2020b, Advanced Hydrologic Prediction Service-Special weather statement-Floyd River at Alton: National Weather Service digital data, accessed April 21, 2020, at https://water. weather.gov/ahps $2 /$ hydrograph.php?wfo=fsd\&gage $=$ alti4 .

National Weather Service [NWS], 2020c, Advanced Hydrologic Prediction Service-Special weather statement-Little Sioux River at Linn Grove: National Weather Service digital data, accessed April 21, 2020, at https://water.weather.gov/ahps2/hydrograph.php?wfo= fsd\&gage=lnni4.

O'Shea, P.S., and Fiala, S.G., 2021, Peak-flow frequency analysis for three selected streamgages in the Cedar and Little Sioux River Basins, Iowa, based on data through water year 2019: U.S. Geological Survey data release, accessed February 18, 2021, at https://doi.org/10.5066/P9W7VP64.

Price, J.A., 2010, Sioux City's Grand Avenue Viaduct1936-2010: Iowa City, Iowa, Tallgrass Historians L.C., 20 p., accessed October 7, 2020, at https://www.iowadot.gov/ ole/documents/SiouxCitysGrandAvenueViaduct.pdf.

Prior, J.C., 1991, Landforms of Iowa: Iowa City, Iowa, University of Iowa Press, $168 \mathrm{p}$.

Rostvedt, J.O., 1968, Summary of floods in the United States during 1962: U.S. Geological Survey Water Supply Paper 1820, 134 p., accessed October 8, 2020, at https://doi.org/ 10.3133/wsp1820.

Schwob, H.H., 1966, Little Sioux River Basin floods: U.S. Geological Survey Open-File Report 67-196, 60 p., accessed May 1, 2019, at https://doi.org/10.3133/ofr67196.

Sioux City History, 2021, Floyd River Flood of 1892: Sioux City History web page, accessed February 9, 2021, at http://www.siouxcityhistory.org/disasters/93-floyd-riverflood-of-1892.

U.S. Bureau of Labor Statistics, 2022, CPI inflation calculator: U.S. Bureau of Labor Statistics web page, accessed February 2, 2022, at https://www.bls.gov/data/inflation calculator.htm. 
U.S. Geological Survey [USGS], 2019, National Hydrography Dataset: U.S. Geological Survey digital data, accessed June 7, 2019, at https://nhd.usgs.gov/NHD_High_ Resolution.html.

U.S. Geological Survey [USGS], 2020a, USGS water data for the Nation: U.S. Geological Survey National Water Information System database, accessed October 10, 2020, at https://doi.org/10.5066/F7P55KJN.

U.S. Geological Survey [USGS], 2020b, USGS 06600100 Floyd River at Alton, IA, in USGS water data for the Nation: U.S. Geological Survey National Water Information System database, accessed December 31, 2020, at https://doi.org/10.5066/F7P55KJN. [Site information directly accessible at https://waterdata.usgs.gov/nwisweb/ get_ratings?file_type $=$ exsa\&site_no $=06600100$.]

U.S. Geological Survey [USGS], 2020c, USGS 06605850 Little Sioux River at Linn Grove, IA, in USGS water data for the Nation: U.S. Geological Survey National Water Information System database, accessed December 31, 2020, at https://doi.org/10.5066/F7P55KJN. [Site information directly accessible at https://waterdata.usgs.gov/nwisweb/ get_ratings?file_type $=$ exsa\&site_no $=06605850$.]
U.S. Geological Survey [USGS], 2021, How streamflow is measured: U.S. Geological Survey web page, accessed May 10, 2021, at https://www.usgs.gov/special-topic/waterscience-school/science/how-streamflow-measured? qt-science_center_objects=0\#qt-science_center_objects.

Van Buskirk, B., 2018, Flooding strikes Plymouth County: Le Mars Daily Sentinel, June 25, 2018, accessed December 2, 2019, at https://www.lemarssentinel.com/story/ 2533264.html.

Wahl, K.D., Meyer, M.J., and Karsten, R.A., 1982, Hydrology of the surficial aquifer in the Floyd River Basin, Iowa: Iowa Geological Survey Water Supply Bulletin 12, 53 p., accessed October 7, 2020, at https://pubs.er.usgs.gov/ publication/70174098.

Wells, J.V.B., 1955, Floods of June 1953 in northwestern Iowa: U.S. Geological Survey Water-Supply Paper 1320, chap. A, accessed October 8, 2020, at 68 p., at https://doi.org/10.3133/wsp1320A. 


\section{Appendix 1. List of Bench Marks and Reference Points}

The U.S. Geological Survey (USGS) used the bench marks, temporary bench marks, and reference points listed in tables 1.1 and 1.2 to facilitate measuring and referencing the elevations of high-water marks (HWMs), low-flow water surfaces, bridge decks, and low-bridge chords. All bench marks, temporary bench marks, and reference-point elevations listed in tables 1.1 and 1.2 are referenced to the North American Vertical Datum of 1988. The temporary bench marks were established at sites where bench marks were not available. In general, bench marks are points that were specifically designed to mark an elevation, such as USGS elevation disks and Iowa Department of Transportation bench marks (round top rods embedded in concrete at one or more corners of a bridge). Marks - such as chiseled squares, chiseled arrows, concrete anchors, or file marks - were used as temporary bench marks or reference points. Reference points were established above water on the downstream side of each bridge to facilitate measuring low-flow water-surface elevations. Users are cautioned that the bench marks, temporary bench marks, and reference points used for this flood profile may have been altered or destroyed since being used in 2018 .

The bench marks, temporary bench marks, and reference points are listed in upstream to downstream order. The bench marks, temporary bench marks, and reference points are identified by an index number composed of the Public Land Survey System township, range, section number, and quarter section for each location; for example, T81N R24W $25 \mathrm{SW}$ means "township 81 north, range 24 west, section 25 , southwest quarter section." Where two or more bench marks/ reference points are in the same location, the points are distinguished by a sequence number in parentheses. The terms "right" and "left" in the description refer to the side of the river determined as viewed while facing in the downstream direction.

USGS survey crews established bench marks, temporary bench marks, and reference-point elevations (tables 1.1 and 1.2) using a Global Navigation Satellite System (GNSS) approach with the objective to achieve a level II or level III quality category survey as referenced from Rydlund and Densmore (2012). The GNSS survey approach involved real-time positioning using the Iowa Real-Time Network SmartNET, a GNSS reference station network service provided by Iowa Department of Transportation and Leica Geosystems (Iowa Department of Transportation, 2018), and suitable published bench marks to provide checks and localizations for resulting GNSS-derived bench mark, temporary bench mark, and reference-point elevations. Bench mark check-ins and check outs along with "blunder checks" were completed as outlined in Rydlund and Densmore (2012). In the absence of suitable published bench marks, deviations were taken from referenced level II and level III protocols such that a hybrid approach was developed with redundant observations to provide an element of quality assurance. Differential and trigonometric leveling were used to perpetuate elevation from fiducial monuments to the HWMs. Differential leveling followed procedures and closure requirements as referenced from Kenney (2010). A modified trigonometric leveling approach using a total station also was used, assuring all backsight and foresight checks were within 0.10 foot (ft) among an open loop traverse.

GNSS Iowa Real-Time Network SmartNET surveys used to establish bench mark, temporary bench mark, and reference-point elevations in tables 1.1 and 1.2 represented uncertainties that were derived from published bench marks. These published marks were used to localize and constrain GNSS observations for many of the temporary bench marks and reference-point elevations whereas others were simply used to check elevations. Overall uncertainty associated with the published marks in tables 1.1 and 1.2 range from 0.10 to $0.35 \mathrm{ft}$. Subsequent HWM uncertainties ranged from 0.05 to $0.4 \mathrm{ft}$, as documented in the Flood Event Viewer with accompanying metadata (Koenig and others, 2016). 
Table 1.1. Bench marks and reference points used in the Floyd River flood profile, flood of June 21-24, 2018, northwestern lowa.

[Bench marks and reference points are listed in upstream order. Where two or more bench marks/reference points are in the same location, the points are distinguished by a sequence number in parentheses. NAVD 88, North American Vertical Datum of 1988; BM, bench mark; USGS, U.S. Geological Survey; GNSS, Global Navigation Satellite System; RP, reference point; TBM, temporary bench mark; CSG, crest-stage gage; E, East; DOT, Department of Transportation; NA, not applicable]

\begin{tabular}{|c|c|c|c|c|c|}
\hline $\begin{array}{c}\text { Public Land Survey System } \\
\text { (township, range, section, quarter section, } \\
\text { sequence number at same location) }\end{array}$ & $\begin{array}{c}\text { Mark } \\
\text { classification }\end{array}$ & Location & Mark & $\begin{array}{c}\text { Elevation } \\
\text { (feet above NAVD 88) }\end{array}$ & $\begin{array}{c}\text { Elevation } \\
\text { determination } \\
\text { method }\end{array}$ \\
\hline T97N R43W 25 SE (1) & $\mathrm{BM}$ & $\begin{array}{l}\text { At Sheldon on U.S. Highway } 18 \text { over Floyd River, on } \\
\text { left downstream side of bridge. }\end{array}$ & $\begin{array}{l}\text { 3/8-inch anchor } \\
\text { and USGS } \\
\text { washer }\end{array}$ & $1,389.69$ & GNSS \\
\hline T97N R43W 25 SE (2) & $\mathrm{RP}$ & $\begin{array}{l}\text { At Sheldon on U.S. Highway } 18 \text { over Floyd River, on } \\
\text { downstream bridge rail, } 3 \text { feet west of radar mount } \\
\text { on bridge. }\end{array}$ & $\begin{array}{l}\text { 3/8-inch anchor } \\
\text { and USGS } \\
\text { washer }\end{array}$ & $1,389.31$ & GNSS \\
\hline T97N R43W 36 SW (1) & $\mathrm{BM}$ & $\begin{array}{l}\text { At Sheldon on 330th Street over Floyd River, on left } \\
\text { downstream side of bridge. }\end{array}$ & $\begin{array}{l}\text { 3/8-inch anchor } \\
\text { and USGS } \\
\text { washer }\end{array}$ & $1,376.11$ & GNSS \\
\hline T97N R43W 36 SW (2) & $\mathrm{RP}$ & $\begin{array}{l}\text { At Sheldon on 330th Street over Floyd River, on 12th } \\
\text { vertical from left downstream side of bridge. }\end{array}$ & $\begin{array}{l}3 \text { chiseled } \\
\text { marks }\end{array}$ & $1,377.76$ & GNSS \\
\hline T96N R36W 14 NE (1) & $\mathrm{BM}$ & $\begin{array}{l}\text { About } 2.5 \text { miles south of Sheldon on } 350 \text { th Street } \\
\text { over Floyd River, on right downstream side of } \\
\text { bridge on inside of bridge deck. }\end{array}$ & $\begin{array}{l}\text { 3/8-inch anchor } \\
\text { and USGS } \\
\text { washer }\end{array}$ & $1,366.15$ & GNSS \\
\hline T96N R36W 14 NE (2) & $\mathrm{RP}$ & $\begin{array}{l}\text { About } 2.5 \text { miles south of Sheldon on 350th Street } \\
\text { over Floyd River, between 12th and 13th vertical } \\
\text { from right to left. }\end{array}$ & $\begin{array}{l}\text { 3/8-inch anchor } \\
\text { and USGS } \\
\text { washer }\end{array}$ & $1,366.11$ & GNSS \\
\hline T96N R43W 23 NW (1) & TBM & $\begin{array}{l}\text { About } 3.5 \text { miles south of Sheldon on 360th Street } \\
\text { bridge over Floyd River, on left upstream side of } \\
\text { bridge, about } 10 \text { feet left of edge of concrete. }\end{array}$ & $\begin{array}{l}2005 \text { U.S. } \\
\text { quarter }\end{array}$ & $1,362.15$ & GNSS \\
\hline T96N R43W 23 NW (2) & $\mathrm{RP}$ & $\begin{array}{l}\text { About } 3.5 \text { miles south of Sheldon on } 360 \text { th Street } \\
\text { bridge over Floyd River, in line with } 22 \mathrm{~d} \text { vertical } \\
\text { from left downstream side of bridge. }\end{array}$ & $\begin{array}{l}\text { 3/8-inch anchor } \\
\text { and USGS } \\
\text { washer }\end{array}$ & $1,361.51$ & GNSS \\
\hline T96N R43W 34 NE (1) & $\mathrm{BM}$ & $\begin{array}{l}\text { About } 2 \text { miles north of Hospers on 380th Street } \\
\text { bridge over Floyd River, on right downstream side } \\
\text { of bridge. }\end{array}$ & $\begin{array}{l}\text { 3/8-inch anchor } \\
\text { and USGS } \\
\text { washer }\end{array}$ & $1,347.19$ & GNSS \\
\hline T96N R43W 34 NE (2) & $\mathrm{RP}$ & $\begin{array}{l}\text { About } 2 \text { miles north of Hospers on 380th Street } \\
\text { bridge over Floyd River, on downstream bridge } \\
\text { rail, about } 4 \text { feet downstream from CSG bracket. }\end{array}$ & $\begin{array}{l}\text { 3/8-inch anchor } \\
\text { and USGS } \\
\text { washer }\end{array}$ & $1,346.40$ & GNSS \\
\hline T95N R43W 10 NW (1) & $\mathrm{BM}$ & $\begin{array}{l}\text { At Hospers on 400th Street bridge over Floyd River, } \\
\text { on left downstream side of bridge. }\end{array}$ & $\begin{array}{l}\text { 3/8-inch anchor } \\
\text { and USGS } \\
\text { washer }\end{array}$ & $1,338.85$ & GNSS \\
\hline T95N R43W 10 NW (2) & $\mathrm{RP}$ & $\begin{array}{l}\text { At Hospers on 400th Street bridge over Floyd River, } \\
25 \text { verticals from left downstream side of bridge. }\end{array}$ & $\begin{array}{l}3 \text { chiseled } \\
\text { marks }\end{array}$ & $1,338.50$ & GNSS \\
\hline
\end{tabular}


Table 1.1. Bench marks and reference points used in the Floyd River flood profile, flood of June 21-24, 2018, northwestern lowa.-Continued

[Bench marks and reference points are listed in upstream order. Where two or more bench marks/reference points are in the same location, the points are distinguished by a sequence number in parentheses. NAVD 88, North American Vertical Datum of 1988; BM, bench mark; USGS, U.S. Geological Survey; GNSS, Global Navigation Satellite System; RP, reference point; TBM, temporary bench mark; CSG, crest-stage gage; E, East; DOT, Department of Transportation; NA, not applicable]

\begin{tabular}{|c|c|c|c|c|c|}
\hline $\begin{array}{c}\text { Public Land Survey System } \\
\text { (township, range, section, quarter section, } \\
\text { sequence number at same location) }\end{array}$ & $\begin{array}{c}\text { Mark } \\
\text { classification }\end{array}$ & Location & Mark & $\begin{array}{c}\text { Elevation } \\
\text { (feet above NAVD 88) }\end{array}$ & $\begin{array}{c}\text { Elevation } \\
\text { determination } \\
\text { method }\end{array}$ \\
\hline T95N R43W 16 NW (1) & $\mathrm{BM}$ & $\begin{array}{l}\text { About } 1 \text { mile south of Hospers on } 410 \text { th Street bridge } \\
\text { over Floyd River, on left downstream side of } \\
\text { bridge, about } 10 \text { feet from edge of concrete. }\end{array}$ & $\begin{array}{l}\text { 3/8-inch anchor } \\
\text { and USGS } \\
\text { washer }\end{array}$ & $1,332.52$ & GNSS \\
\hline T95N R43W 16 NW (2) & $\mathrm{RP}$ & $\begin{array}{l}\text { About } 1 \text { mile south of Hospers on } 410 \text { th Street bridge } \\
\text { over Floyd River, on } 8 \text { th vertical from right down- } \\
\text { stream side of bridge. }\end{array}$ & $\begin{array}{l}\text { 3/8-inch anchor } \\
\text { and USGS } \\
\text { washer }\end{array}$ & $1,331.99$ & GNSS \\
\hline T95N R43W 20 SE (1) & $\mathrm{BM}$ & $\begin{array}{l}\text { About } 3 \text { miles south of Hospers on 430th Street } \\
\text { bridge over Floyd River. }\end{array}$ & USGS BM & $1,312.62$ & GNSS \\
\hline T95N R43W 20 SE (2) & $\mathrm{RP}$ & $\begin{array}{l}\text { About } 3 \text { miles south of Hospers on 430th Street } \\
\text { bridge over Floyd River, on } 6 \text { th vertical from left } \\
\text { to right on downstream side of bridge. }\end{array}$ & $\begin{array}{l}3 \text { chiseled } \\
\text { marks }\end{array}$ & $1,312.65$ & GNSS \\
\hline T95N R44W 25 SE (1) & $\mathrm{BM}$ & $\begin{array}{l}\text { About } 1.5 \text { miles north of Alton on Kingbird Avenue } \\
\text { bridge over Floyd River, on left downstream side } \\
\text { of bridge. }\end{array}$ & $\begin{array}{l}\text { 3/8-inch anchor } \\
\text { and USGS } \\
\text { washer }\end{array}$ & $1,309.74$ & GNSS \\
\hline T95N R44W 25 SE (2) & $\mathrm{RP}$ & $\begin{array}{l}\text { About } 1.5 \text { miles north of Alton on Kingbird Avenue } \\
\text { bridge over Floyd River, on } 8 \text { th vertical from right } \\
\text { to left on downstream side of bridge. }\end{array}$ & $\begin{array}{l}3 \text { chiseled } \\
\text { marks }\end{array}$ & $1,311.69$ & GNSS \\
\hline T95N R44W 35 SW (1) & $\mathrm{BM}$ & $\begin{array}{l}\text { About } 0.5 \text { mile north of Alton on Kennedy Avenue } \\
\text { bridge over Floyd River, on right downstream side } \\
\text { of bridge, } 5 \text { feet from yellow sign. }\end{array}$ & $\begin{array}{l}\text { 3/8-inch anchor } \\
\text { and USGS } \\
\text { washer }\end{array}$ & $1,309.77$ & GNSS \\
\hline T95N R44W 35 SW (2) & $\mathrm{RP}$ & $\begin{array}{l}\text { About } 0.5 \text { mile north of Alton on Kennedy Avenue } \\
\text { bridge over Floyd River, between } 17 \text { th and } 18 \text { th } \\
\text { vertical from right to left on downstream side of } \\
\text { bridge. }\end{array}$ & $\begin{array}{l}\text { 3/8-inch anchor } \\
\text { and USGS } \\
\text { washer }\end{array}$ & $1,307.71$ & GNSS \\
\hline T94N R44W 11 NE (1) & $\mathrm{BM}$ & $\begin{array}{l}\text { At Alton, site of streamgage } 06600100 \text { Floyd River } \\
\text { at Alton, on E Division Street bridge over Floyd } \\
\text { River, on right downstream base of wingwall. }\end{array}$ & Chiseled square & $1,300.20$ & $\begin{array}{l}\text { Streamgage } \\
\text { elevation data }\end{array}$ \\
\hline T94N R44W 11 NE (2) & $\mathrm{BM}$ & $\begin{array}{l}\text { At Alton on Highway } 60 \text { bridge over Floyd River, on } \\
\text { right downstream side of bridge. }\end{array}$ & $\begin{array}{l}\text { Iowa DOT } \\
\text { bench mark }\end{array}$ & $1,309.70$ & GNSS \\
\hline T94N R44W 11 NE (3) & $\mathrm{RP}$ & $\begin{array}{l}\text { At Alton on Highway } 60 \text { bridge over Floyd River, on } \\
\text { middle downstream side of bridge. }\end{array}$ & Chiseled square & $1,305.68$ & GNSS \\
\hline T94N R44W 28 NE (1) & TBM & $\begin{array}{l}\text { About } 3 \text { miles south of Alton on 490th Street bridge } \\
\text { over Floyd River, on right downstream side of } \\
\text { bridge. }\end{array}$ & Chiseled $\mathrm{x}$ & $1,283.39$ & GNSS \\
\hline
\end{tabular}


Table 1.1. Bench marks and reference points used in the Floyd River flood profile, flood of June 21-24, 2018, northwestern lowa.-Continued

[Bench marks and reference points are listed in upstream order. Where two or more bench marks/reference points are in the same location, the points are distinguished by a sequence number in parentheses. NAVD 88, North American Vertical Datum of 1988; BM, bench mark; USGS, U.S. Geological Survey; GNSS, Global Navigation Satellite System; RP, reference point; TBM, temporary bench mark; CSG, crest-stage gage; E, East; DOT, Department of Transportation; NA, not applicable]

\begin{tabular}{|c|c|c|c|c|c|}
\hline $\begin{array}{l}\text { Public Land Survey System } \\
\text { (township, range, section, quarter section, } \\
\text { sequence number at same location) }\end{array}$ & $\begin{array}{c}\text { Mark } \\
\text { classification }\end{array}$ & Location & Mark & $\begin{array}{c}\text { Elevation } \\
\text { (feet above NAVD 88) }\end{array}$ & $\begin{array}{c}\text { Elevation } \\
\text { determination } \\
\text { method }\end{array}$ \\
\hline T94N R44W 28 NE (2) & $\mathrm{RP}$ & $\begin{array}{l}\text { About } 3 \text { miles south of Alton on 490th Street bridge } \\
\text { over Floyd River, } 16 \text { verticals from right down- } \\
\text { stream side of bridge. }\end{array}$ & Chiseled arrow & $1,283.43$ & GNSS \\
\hline T93N R44W 7 NE (1) & TBM & $\begin{array}{l}\text { About } 7 \text { miles north of Le Mars on County Road C12 } \\
\text { bridge over Floyd River, on left downstream side } \\
\text { of bridge. }\end{array}$ & Painted bolt & $1,254.79$ & GNSS \\
\hline T93N R44W 7 NE (2) & $\mathrm{RP}$ & $\begin{array}{l}\text { About } 7 \text { miles north of Le Mars on County Road } \\
\text { C12 bridge over Floyd River, } 10 \text { verticals from left } \\
\text { downstream side of bridge. }\end{array}$ & $\begin{array}{l}3 \text { chiseled } \\
\text { marks }\end{array}$ & $1,255.58$ & GNSS \\
\hline T93N R45W 13 SW (1) & $\mathrm{BM}$ & $\begin{array}{l}\text { About } 5 \text { miles north of Le Mars on County Road C16 } \\
\text { bridge over Floyd River, on right downstream side } \\
\text { of bridge. }\end{array}$ & $\begin{array}{l}\text { Plymouth } \\
\text { County BM }\end{array}$ & $1,241.51$ & GNSS \\
\hline T93N R45W 13 SW (2) & $\mathrm{RP}$ & $\begin{array}{l}\text { About } 5 \text { miles north of Le Mars on County Road C16 } \\
\text { bridge over Floyd River, on middle downstream } \\
\text { side of bridge, } 13 \text { verticals from right to left. }\end{array}$ & Chiseled square & $1,241.35$ & GNSS \\
\hline T93N R45W 26 NW (1) & TBM & $\begin{array}{l}\text { About } 4 \text { miles north of Le Mars on 140th Street } \\
\text { bridge over Floyd River, on right downstream side } \\
\text { of bridge on rivet. }\end{array}$ & Chiseled $\mathrm{x}$ & $1,233.17$ & GNSS \\
\hline T93N R45W 26 NW (2) & $\mathrm{RP}$ & $\begin{array}{l}\text { About } 4 \text { miles north of Le Mars on 140th Street } \\
\text { bridge over Floyd River, on middle downstream } \\
\text { side of bridge. On right side truss, } 17 \text { rivets angle } \\
\text { in truss to the left. }\end{array}$ & $\begin{array}{l}3 \text { chiseled } \\
\text { marks }\end{array}$ & $1,241.16$ & GNSS \\
\hline T93N R45W 27 SW (1) & TBM & $\begin{array}{l}\text { About } 3 \text { miles north of Le Mars on 150th Street } \\
\text { bridge over Floyd River, on right downstream side } \\
\text { of bridge. }\end{array}$ & Chiseled $\mathrm{x}$ & $1,228.85$ & GNSS \\
\hline T93N R45W 27 SW (2) & $\mathrm{RP}$ & $\begin{array}{l}\text { About } 3 \text { miles north of Le Mars on 150th Street } \\
\text { bridge over Floyd River, on 10th vertical from } \\
\text { right downstream side of bridge. }\end{array}$ & NA & $1,228.98$ & GNSS \\
\hline T93N R45W 33 SE (1) & $\mathrm{BM}$ & $\begin{array}{l}\text { About } 2 \text { miles north of Le Mars on 160th Street } \\
\text { bridge over Floyd River. }\end{array}$ & $\begin{array}{l}\text { Plymouth } \\
\text { County BM }\end{array}$ & $1,223.67$ & GNSS \\
\hline T93N R45W 33 SE (2) & $\mathrm{RP}$ & $\begin{array}{l}\text { About } 2 \text { miles north of Le Mars on 160th Street } \\
\text { bridge over Floyd River, on middle downstream } \\
\text { side of bridge, near } 15 \text { vertical from right bank. }\end{array}$ & Chiseled square & $1,223.49$ & GNSS \\
\hline
\end{tabular}


Table 1.1. Bench marks and reference points used in the Floyd River flood profile, flood of June 21-24, 2018, northwestern lowa.-Continued

[Bench marks and reference points are listed in upstream order. Where two or more bench marks/reference points are in the same location, the points are distinguished by a sequence number in parentheses NAVD 88, North American Vertical Datum of 1988; BM, bench mark; USGS, U.S. Geological Survey; GNSS, Global Navigation Satellite System; RP, reference point; TBM, temporary bench mark; CSG, crest-stage gage; E, East; DOT, Department of Transportation; NA, not applicable]

\begin{tabular}{|c|c|c|c|c|c|}
\hline $\begin{array}{c}\text { Public Land Survey System } \\
\text { (township, range, section, quarter section, } \\
\text { sequence number at same location) }\end{array}$ & $\begin{array}{c}\text { Mark } \\
\text { classification }\end{array}$ & Location & Mark & $\begin{array}{c}\text { Elevation } \\
\text { (feet above NAVD 88) }\end{array}$ & $\begin{array}{c}\text { Elevation } \\
\text { determination } \\
\text { method }\end{array}$ \\
\hline T92N R45W 9 NW (1) & TBM & $\begin{array}{l}\text { At Le Mars on Highway } 75 \text { bridge over Floyd River, } \\
\text { on left downstream side of bridge. }\end{array}$ & Chiseled $\mathrm{x}$ & $1,216.05$ & GNSS \\
\hline T92N R45W 9 NW (2) & $\mathrm{RP}$ & $\begin{array}{l}\text { At Le Mars on Highway } 75 \text { bridge over Floyd River, } \\
3 \text { feet past } 22 \mathrm{~d} \text { drain from left downstream side of } \\
\text { bridge. }\end{array}$ & Chiseled square & $1,214.25$ & GNSS \\
\hline T92N R45W 8 SE (1) & TBM & $\begin{array}{l}\text { At Le Mars on Highway } 3 \text { bridge over Floyd River, } \\
\text { on left downstream side of bridge. }\end{array}$ & Chiseled square & $1,212.15$ & GNSS \\
\hline T92N R45W 8 SE (2) & $\mathrm{RP}$ & $\begin{array}{l}\text { At Le Mars on Highway } 3 \text { bridge over Floyd River, } \\
\text { RP not located, measurement made from top of } \\
\text { railing on middle, downstream side of bridge. }\end{array}$ & NA & $1,212.93$ & GNSS \\
\hline
\end{tabular}


Table 1.2. Bench marks and reference points used in the Little Sioux River flood profile, flood of June 27-July 1, 2018, northwestern lowa.

[Bench marks and reference points are listed in upstream order. Where two or more bench marks/reference points are in the same location, the points are distinguished by a sequence number in parentheses. NAVD 88, North American Vertical Datum of 1988; RP, reference point; GNSS, Global Navigation Satellite System; BM, bench mark; W, West; DOT, Department of Transportation; USGS, U.S. Geological Survey; TBM, temporary bench mark; E, East]

\begin{tabular}{|c|c|c|c|c|c|}
\hline $\begin{array}{c}\text { Public Land Survey System } \\
\text { (township, range, section, quarter section, } \\
\text { sequence number at same location) }\end{array}$ & $\begin{array}{c}\text { Mark } \\
\text { classification }\end{array}$ & Location & Mark & $\begin{array}{c}\text { Elevation } \\
\text { (feet above NAVD 88) }\end{array}$ & $\begin{array}{c}\text { Elevation } \\
\text { determination } \\
\text { method }\end{array}$ \\
\hline T97N R37W 27 SE (1) & $\mathrm{RP}$ & $\begin{array}{l}\text { About } 3 \text { miles north of Spencer on 320th Street } \\
\text { bridge over Little Sioux River, on downstream side } \\
\text { of bridge between 10th and 11th metal square from } \\
\text { right to left. About } 3 \text { feet to the left of Iowa Flood } \\
\text { Center box. }\end{array}$ & $\begin{array}{l}3 \text { chiseled } \\
\text { marks }\end{array}$ & $1,332.91$ & GNSS \\
\hline T96N R37W 11 NW (1) & $\mathrm{RP}$ & $\begin{array}{l}\text { About } 1.5 \text { miles west of Spencer on } 18 \text { th Street } \\
\text { bridge over Little Sioux River, } 13 \text { verticals from } \\
\text { right downstream side of bridge. }\end{array}$ & $\begin{array}{l}2 \text { chiseled } \\
\text { marks }\end{array}$ & $1,327.68$ & GNSS \\
\hline T96N R37W 11 SW (1) & $\mathrm{BM}$ & $\begin{array}{l}\text { About } 1.5 \text { miles west of Spencer on W 4th Street } \\
\text { bridge over Little Sioux River, on right upstream } \\
\text { side of bridge. }\end{array}$ & Iowa DOT BM & $1,326.18$ & GNSS \\
\hline T96N R37W 11 SW (2) & $\mathrm{RP}$ & $\begin{array}{l}\text { About } 1.5 \text { miles west of Spencer on W 4th Street } \\
\text { bridge over Little Sioux River, on 13th vertical } \\
\text { from right downstream side of bridge. }\end{array}$ & $\begin{array}{l}3 \text { chiseled } \\
\text { marks }\end{array}$ & $1,325.54$ & GNSS \\
\hline T96N R36W 18 NW (1) & $\mathrm{RP}$ & $\begin{array}{l}\text { At Spencer on U.S. Highway } 71 \text { bridge over Little } \\
\text { Sioux River, near wire box on downstream side of } \\
\text { bridge. }\end{array}$ & $\begin{array}{l}3 \text { chiseled } \\
\text { marks }\end{array}$ & $1,318.75$ & GNSS \\
\hline T96N R36W 17 SE (1) & $\mathrm{BM}$ & $\begin{array}{l}\text { About } 1.5 \text { miles east of Spencer on County Road } \\
\text { M50 bridge over Little Sioux River, on left up- } \\
\text { stream side of bridge. }\end{array}$ & Metal spike & $1,316.81$ & GNSS \\
\hline T96N R36W 17 SE (2) & $\mathrm{RP}$ & $\begin{array}{l}\text { About } 1.5 \text { miles east of Spencer on County Road } \\
\text { M50 bridge over Little Sioux River, } 2 \text { feet past } \\
\text { 14th vertical from left downstream side of bridge. }\end{array}$ & Chiseled square & $1,316.44$ & GNSS \\
\hline T96N R36W 15 SE (1) & $\mathrm{BM}$ & $\begin{array}{l}\text { About } 3 \text { miles east of Spencer on Highway } 18 \text { bridge } \\
\text { over Little Sioux River, on right downstream side } \\
\text { of bridge directly north of Little Sioux River sign. }\end{array}$ & $\begin{array}{l}\text { 3/8-inch bolt } \\
\text { and USGS } \\
\text { washer }\end{array}$ & $1,314.26$ & GNSS \\
\hline T96N R36W 15 SE (2) & $\mathrm{RP}$ & $\begin{array}{l}\text { About } 3 \text { miles east of Spencer on Highway } 18 \text { bridge } \\
\text { over Little Sioux River, on outside of downstream } \\
\text { bridge wall directly above } 7 \text { th drain hole from right } \\
\text { to left. }\end{array}$ & $\begin{array}{l}\text { 3/8-inch bolt } \\
\text { and USGS } \\
\text { washer }\end{array}$ & $1,314.63$ & GNSS \\
\hline T96N R36W 35 SW (1) & $\mathrm{BM}$ & $\begin{array}{l}\text { About } 3 \text { miles south of Spencer on County Road B40 } \\
\text { bridge over Little Sioux River, between } 21 \text { st and } \\
22 \mathrm{~d} \text { vertical from right to left on outside of bridge } \\
\text { walk on downstream side of bridge. }\end{array}$ & $\begin{array}{l}\text { 3/8-inch bolt } \\
\text { and USGS } \\
\text { washer }\end{array}$ & $1,301.29$ & GNSS \\
\hline
\end{tabular}


[Bench marks and reference points are listed in upstream order. Where two or more bench marks/reference points are in the same location, the points are distinguished by a sequence number in parentheses. NAVD 88, North American Vertical Datum of 1988; RP, reference point; GNSS, Global Navigation Satellite System; BM, bench mark; W, West; DOT, Department of Transportation; USGS, U.S. Geological Survey; TBM, temporary bench mark; E, East]

\begin{tabular}{|c|c|c|c|c|c|}
\hline $\begin{array}{l}\text { Public Land Survey System } \\
\text { (township, range, section, quarter section, } \\
\text { sequence number at same location) }\end{array}$ & $\begin{array}{c}\text { Mark } \\
\text { classification }\end{array}$ & Location & Mark & $\begin{array}{c}\text { Elevation } \\
\text { (feet above NAVD 88) }\end{array}$ & $\begin{array}{c}\text { Elevation } \\
\text { determination } \\
\text { method }\end{array}$ \\
\hline T96N R36W 35 SW (2) & $\mathrm{RP}$ & $\begin{array}{l}\text { About } 3 \text { miles south of Spencer on County Road B } 40 \\
\text { bridge over Little Sioux River, between } 21 \text { st and } \\
22 \mathrm{~d} \text { vertical from right to left on outside of bridge } \\
\text { walk on downstream side of bridge. }\end{array}$ & $\begin{array}{l}\text { 3/8-inch bolt } \\
\text { and USGS } \\
\text { washer }\end{array}$ & $1,301.98$ & GNSS \\
\hline T95N R36W 25 NW (1) & TBM & $\begin{array}{l}\text { At Gillett Grove on County Road B53 bridge over } \\
\text { Little Sioux River, on left upstream side of bridge. }\end{array}$ & Chiseled square & $1,294.19$ & GNSS \\
\hline T95N R36W 25 NW (2) & $\mathrm{RP}$ & $\begin{array}{l}\text { At Gillett Grove on County Road B53 bridge over } \\
\text { Little Sioux River, } 25 \text { verticals from right down- } \\
\text { stream side of bridge. }\end{array}$ & $\begin{array}{l}2 \text { chiseled } \\
\text { marks }\end{array}$ & $1,295.04$ & GNSS \\
\hline T95N R36W 34 SE (1) & TBM & $\begin{array}{l}\text { About } 1.5 \text { miles south of Gillet Grove on 260th } \\
\text { Avenue bridge over Little Sioux River, on left } \\
\text { downstream side of bridge. }\end{array}$ & Chiseled $\mathrm{x}$ & $1,290.63$ & GNSS \\
\hline T95N R36W 34 SE (2) & $\mathrm{RP}$ & $\begin{array}{l}\text { About } 1.5 \text { miles south of Gillet Grove on } 260 \text { th } \\
\text { Avenue bridge over Little Sioux River, } 16 \text { verticals } \\
\text { from left downstream side of bridge. }\end{array}$ & $\begin{array}{l}2 \text { chiseled } \\
\text { marks }\end{array}$ & $1,290.34$ & GNSS \\
\hline T94N R36W 9 SW (1) & TBM & $\begin{array}{l}\text { About } 2 \text { miles north of Cornell on 240th Street bridge } \\
\text { over Little Sioux River, on left upstream side of } \\
\text { bridge. Furthest southeast bolt on outside of bridge. }\end{array}$ & $\begin{array}{l}\text { Bolt with chis- } \\
\quad \text { eled } \mathrm{x}\end{array}$ & $1,278.11$ & GNSS \\
\hline T94N R36W 9 SW (2) & $\mathrm{RP}$ & $\begin{array}{l}\text { About } 2 \text { miles north of Cornell on 240th Street bridge } \\
\text { over Little Sioux River, between } 2 \mathrm{~d} \text { and } 3 \mathrm{~d} \text { vertical } \\
\text { from left to right on downstream side of bridge. } \\
\text { Angled truss member is not counted as a vertical. }\end{array}$ & $\begin{array}{l}3 \text { chiseled } \\
\text { marks }\end{array}$ & $1,278.74$ & GNSS \\
\hline T94N R36W 20 NW (1) & $\mathrm{BM}$ & $\begin{array}{l}\text { About } 1 \text { mile north of Cornell on 480th Street bridge } \\
\text { over Little Sioux River, on right downstream side } \\
\text { of bridge. About } 5 \text { feet south of yellow marker } \\
\text { sign. }\end{array}$ & $\begin{array}{l}\text { 3/8-inch bolt } \\
\text { and USGS } \\
\text { washer }\end{array}$ & $1,290.58$ & GNSS \\
\hline T94N R36W 20 NW (2) & $\mathrm{RP}$ & $\begin{array}{l}\text { About } 1 \text { mile north of Cornell on 480th Street bridge } \\
\text { over Little Sioux River, between } 27 \text { th and } 28 \text { th } \\
\text { vertical from right to left on downstream side of } \\
\text { bridge. }\end{array}$ & $\begin{array}{l}\text { 3/8-inch bolt } \\
\text { and USGS } \\
\text { washer }\end{array}$ & $1,284.64$ & GNSS \\
\hline T94N R36W 28 SE (1) & TBM & $\begin{array}{l}\text { About } 2.5 \text { miles north of Sioux Rapids on } 495 \text { th } \\
\text { Street bridge over Little Sioux River, on right } \\
\text { downstream side of bridge. }\end{array}$ & Chiseled $\mathrm{x}$ & $1,281.37$ & GNSS \\
\hline
\end{tabular}


Table 1.2. Bench marks and reference points used in the Little Sioux River flood profile, flood of June 27-July 1, 2018, northwestern lowa.-Continued

[Bench marks and reference points are listed in upstream order. Where two or more bench marks/reference points are in the same location, the points are distinguished by a sequence number in parentheses. NAVD 88, North American Vertical Datum of 1988; RP, reference point; GNSS, Global Navigation Satellite System; BM, bench mark; W, West; DOT, Department of Transportation; USGS, U.S. Geological Survey; TBM, temporary bench mark; E, East]

\begin{tabular}{|c|c|c|c|c|c|}
\hline $\begin{array}{l}\text { Public Land Survey System } \\
\text { (township, range, section, quarter section, } \\
\text { sequence number at same location) }\end{array}$ & $\begin{array}{c}\text { Mark } \\
\text { classification }\end{array}$ & Location & Mark & $\begin{array}{c}\text { Elevation } \\
\text { (feet above NAVD 88) }\end{array}$ & $\begin{array}{l}\text { Elevation } \\
\text { determination } \\
\text { method }\end{array}$ \\
\hline T94N R36W 28 SE (2) & $\mathrm{RP}$ & $\begin{array}{l}\text { About } 2.5 \text { miles north of Sioux Rapids, on } 495 \text { th } \\
\text { Street bridge over Little Sioux River, } 20 \text { verticals } \\
\text { from left downstream side of bridge. }\end{array}$ & Chiseled square & $1,281.02$ & GNSS \\
\hline T93N R37W 1 SE (1) & $\mathrm{BM}$ & $\begin{array}{l}\text { At Sioux Rapids on U.S. Highway } 71 \text { bridge over } \\
\text { Little Sioux River, about } 120 \text { feet from left down- } \\
\text { stream side of bridge. }\end{array}$ & $\begin{array}{l}\text { Capped bolt } \\
\text { labeled JP } \\
\text { Ward }\end{array}$ & $1,270.26$ & GNSS \\
\hline T93N R37W 1 SE (2) & $\mathrm{RP}$ & $\begin{array}{l}\text { At Sioux Rapids on U.S. Highway } 71 \text { bridge over } \\
\text { Little Sioux River, about } 5 \text { feet from bench mark } \\
\text { and between 4th and 5th drain from left to right. }\end{array}$ & $\begin{array}{l}\text { 3/8-inch bolt } \\
\text { and USGS } \\
\text { washer }\end{array}$ & $1,271.35$ & GNSS \\
\hline T93N R37W 5 SE (1) & $\mathrm{BM}$ & $\begin{array}{l}\text { At Linn Grove, site of streamgage } 06605850 \text { Little } \\
\text { Sioux River at Linn Grove, east of Main Street, on } \\
\text { the concrete base of the gage shelter on the down- } \\
\text { stream streamward corner. }\end{array}$ & $\begin{array}{l}\text { 3/8-inch stud } \\
\text { and nut }\end{array}$ & $1,261.51$ & $\begin{array}{l}\text { Streamgage eleva- } \\
\text { tion data }\end{array}$ \\
\hline T93N R37W 5 SE (2) & TBM & $\begin{array}{l}\text { At Linn Grove on Weaver Street bridge over Little } \\
\text { Sioux River, on right downstream side of bridge. }\end{array}$ & Chiseled square & $1,261.50$ & GNSS \\
\hline T93N R37W 5 SE (3) & $\mathrm{RP}$ & $\begin{array}{l}\text { At Linn Grove on Weaver Street bridge over Little } \\
\text { Sioux River, } 13 \text { verticals from right downstream } \\
\text { side of bridge. }\end{array}$ & Chiseled $\mathrm{x}$ & $1,260.66$ & GNSS \\
\hline T94N R38W 33 SW (1) & $\mathrm{BM}$ & $\begin{array}{l}\text { At Peterson on 125th Street bridge over Little Sioux } \\
\text { River, on left downstream side of bridge. }\end{array}$ & $\begin{array}{l}\text { 3/8-inch bolt } \\
\text { and USGS } \\
\text { washer }\end{array}$ & $1,238.84$ & GNSS \\
\hline T94N R38W 33 SW (2) & $\mathrm{RP}$ & $\begin{array}{l}\text { At Peterson on } 125 \text { th Street bridge over Little Sioux } \\
\text { River, } 16 \text { verticals from left downstream side of } \\
\text { bridge. }\end{array}$ & $\begin{array}{l}3 \text { chiseled } \\
\text { marks }\end{array}$ & $1,241.54$ & GNSS \\
\hline T94N R38W 32 NE (1) & $\mathrm{BM}$ & $\begin{array}{l}\text { At Peterson on Highway } 10 \text { bridge over Little Sioux } \\
\text { River, on left downstream side of bridge. }\end{array}$ & Iowa DOT BM & $1,239.32$ & GNSS \\
\hline T94N R38W 32 NE (2) & $\mathrm{RP}$ & $\begin{array}{l}\text { At Peterson on Highway } 10 \text { bridge over Little Sioux } \\
\text { River, between } 6 \text { th and } 7 \text { th drain from right down- } \\
\text { stream side of bridge. }\end{array}$ & Chiseled square & $1,237.74$ & GNSS \\
\hline T94N R39W 27 SE (1) & $\mathrm{BM}$ & $\begin{array}{l}\text { About } 4 \text { miles west of Peterson on Highway } 10 \\
\text { bridge over Little Sioux River, on right, upstream } \\
\text { side of bridge. }\end{array}$ & Iowa DOT BM & $1,228.67$ & GNSS \\
\hline
\end{tabular}


[Bench marks and reference points are listed in upstream order. Where two or more bench marks/reference points are in the same location, the points are distinguished by a sequence number in parentheses. NAVD 88, North American Vertical Datum of 1988; RP, reference point; GNSS, Global Navigation Satellite System; BM, bench mark; W, West; DOT, Department of Transportation; USGS, U.S. Geological Survey; TBM, temporary bench mark; E, East]

\begin{tabular}{|c|c|c|c|c|c|}
\hline $\begin{array}{l}\text { Public Land Survey System } \\
\text { (township, range, section, quarter section, } \\
\text { sequence number at same location) }\end{array}$ & $\begin{array}{c}\text { Mark } \\
\text { classification }\end{array}$ & Location & Mark & $\begin{array}{c}\text { Elevation } \\
\text { (feet above NAVD 88) }\end{array}$ & $\begin{array}{c}\text { Elevation } \\
\text { determination } \\
\text { method }\end{array}$ \\
\hline T94N R39W 27 SE (2) & $\mathrm{RP}$ & $\begin{array}{l}\text { About } 4 \text { miles west of Peterson on Highway } 10 \\
\text { bridge over Little Sioux River, } 6 \text { drains from left } \\
\text { downstream side of bridge. }\end{array}$ & Chiseled square & $1,229.89$ & GNSS \\
\hline T93N R39W 21 NW (1) & $\mathrm{BM}$ & $\begin{array}{l}\text { About } 4 \text { miles east of Larrabee on County Road C16 } \\
\text { bridge over Little Sioux River, on left downstream } \\
\text { side of bridge. }\end{array}$ & $\begin{array}{l}\text { 3/8-inch bolt } \\
\text { and USGS } \\
\text { washer }\end{array}$ & $1,211.13$ & GNSS \\
\hline T93N R39W 21 NW (2) & $\mathrm{RP}$ & $\begin{array}{l}\text { About } 4 \text { miles east of Larrabee on County Road C16 } \\
\text { bridge over Little Sioux River, near } 30 \text { th vertical } \\
\text { from right downstream side of bridge; } 3 \text { feet to the } \\
\text { left of wire box. }\end{array}$ & $\begin{array}{l}\text { 3/8-inch bolt } \\
\text { and USGS } \\
\text { washer }\end{array}$ & $1,212.56$ & GNSS \\
\hline T93N R40W 36 SE (1) & $\mathrm{BM}$ & $\begin{array}{l}\text { About } 4.5 \text { miles north of Cherokee on County Road } \\
\text { C25 bridge over Little Sioux River, on left down- } \\
\text { stream side of bridge. }\end{array}$ & $\begin{array}{l}\text { 3/8-inch bolt } \\
\text { and USGS } \\
\text { washer }\end{array}$ & $1,201.98$ & GNSS \\
\hline T93N R40W 36 SE (2) & $\mathrm{RP}$ & $\begin{array}{l}\text { About } 4.5 \text { miles north of Cherokee on County Road } \\
\text { C } 25 \text { bridge over Little Sioux River, between } 25 \text { th } \\
\text { and } 26 \text { th vertical from left to right on downstream } \\
\text { side of bridge. }\end{array}$ & $\begin{array}{l}3 \text { chiseled } \\
\text { marks }\end{array}$ & $1,200.87$ & GNSS \\
\hline T92N R40W 26 NE (1) & TBM & $\begin{array}{l}\text { At Cherokee on Highway } 3 \text { bridge over Little Sioux } \\
\text { River, on left downstream side of bridge. }\end{array}$ & Chiseled $\mathrm{x}$ & $1,189.32$ & GNSS \\
\hline T92N R40W 26 NE (2) & $\mathrm{RP}$ & $\begin{array}{l}\text { At Cherokee on Highway } 3 \text { bridge over Little Sioux } \\
\text { River, between } 4 \text { th and } 5 \text { th drain from left down- } \\
\text { stream side of bridge. }\end{array}$ & Chiseled square & $1,187.90$ & GNSS \\
\hline T92N R40W 35 NW (1) & $\mathrm{RP}$ & $\begin{array}{l}\text { At Cherokee on E Main Street bridge over Little } \\
\text { Sioux River, near 4th drain from right downstream } \\
\text { side of bridge. }\end{array}$ & $\begin{array}{l}\text { 3/8-inch bolt } \\
\text { and USGS } \\
\text { washer }\end{array}$ & $1,189.18$ & GNSS \\
\hline T92N R40W 34 NE (1) & TBM & $\begin{array}{l}\text { At Cherokee on U.S. Highway } 59 \text { bridge over Little } \\
\text { Sioux River, on downstream wall. }\end{array}$ & Chiseled $\mathrm{x}$ & $1,184.55$ & GNSS \\
\hline T92N R40W 34 NE (2) & $\mathrm{RP}$ & $\begin{array}{l}\text { At Cherokee on U.S. Highway } 59 \text { bridge over Little } \\
\text { Sioux River, directly below Weather Bureau box } \\
\text { on downstream side of bridge. }\end{array}$ & Chiseled square & $1,181.71$ & GNSS \\
\hline
\end{tabular}




\section{References Cited}

Iowa Department of Transportation, 2018, Iowa Real-Time Network: Iowa Department of Transportation web page, accessed August 28, 2019, at https://iowadot.gov/rtn/iartnresources/about-the-iartn.

Kenney, T.A., 2010, Levels at gaging stations: U.S. Geological Survey Techniques and Methods, book 3, chap. A19, 60 p. accessed October 2020 at https://doi.org/10.3133/tm3A19.
Koenig, T.A., Bruce, J.L., O’Connor, J.E., McGee, B.D., Holmes, R.R., Jr., Hollins, R., Forbes, B.T., Kohn, M.S., Schellekens, M.F., Martin, Z.W., and Peppler, M.C., 2016, Identifying and preserving high-water mark data: U.S. Geological Survey Techniques and Methods, book 3, chap. A24, 47 p., accessed October 20, 2020, at https://doi.org/10.3133/tm3A24.

Rydlund, P.H., Jr., and Densmore, B.K., 2012, Methods of practice and guidelines for using survey-grade global navigation satellite systems (GNSS) to establish vertical datum in the United States Geological Survey: U.S. Geological Survey Techniques and Methods, book 11, chap. D1, 102 p. with appendixes, accessed October 20, 2020, at https://doi.org/10.3133/tm11D1. 

For more information about this publication, contact: Director, USGS Central Midwest Water Science Center 400 South Clinton Street, Suite 269

lowa City, IA 52240

319-337-4191

For additional information, visit: https://www.usgs.gov/ centers/cm-water

Publishing support provided by the

Lafayette and Rolla Publishing Service Centers 


\section{$\frac{2}{8}$}

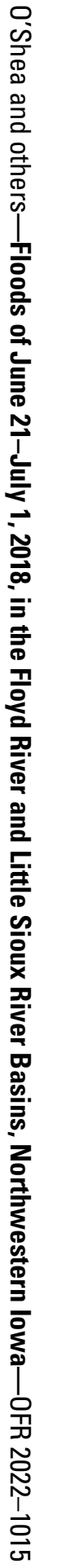

